\title{
High UV and Sunlight Photocatalytic Performance of Porous ZnO Nanostructures Synthesized by a Facile and Fast Microwave Hydrothermal Method
}

\author{
Sofia Henriques Ferreira $(\mathbb{D}$, Maria Morais $(\mathbb{D}$, Daniela Nunes $(\mathbb{D}$, Maria João Oliveira $\mathbb{(}$, Ana Rovisco $(\mathbb{D}$, \\ Ana Pimentel, Hugo Águas (D), Elvira Fortunato* and Rodrigo Martins *(i)
}

check for

updates

Citation: Ferreira, S.H.; Morais, M.; Nunes, D.; Oliveira, M.J.; Rovisco, A.; Pimentel, A.; Águas, H.; Fortunato, E.; Martins, R. High UV and Sunlight Photocatalytic Performance of Porous ZnO Nanostructures Synthesized by a Facile and Fast Microwave Hydrothermal Method. Materials 2021, 14, 2385. https://doi.org/ $10.3390 / \mathrm{ma} 14092385$

Academic Editor: Davide Barreca

Received: 13 April 2021

Accepted: 1 May 2021

Published: 4 May 2021

Publisher's Note: MDPI stays neutral with regard to jurisdictional claims in published maps and institutional affiliations.

Copyright: () 2021 by the authors. Licensee MDPI, Basel, Switzerland. This article is an open access article distributed under the terms and conditions of the Creative Commons Attribution (CC BY) license (https:// creativecommons.org/licenses/by/ $4.0 /)$.
i3N/CENIMAT, Department of Materials Science, Faculty of Science and Technology, Universidade NOVA de Lisboa and CEMOP/UNINOVA, Campus de Caparica, 2829-516 Caparica, Portugal; sdl.ferreira@campus.fct.unl.pt (S.H.F.); md.morais@campus.fct.unl.pt (M.M.); daniela.gomes@fct.unl.pt (D.N.); mj.oliveira@campus.fct.unl.pt (M.J.O.); a.rovisco@campus.fct.unl.pt (A.R.); acgp@campus.fct.unl.pt (A.P.); hma@fct.unl.pt (H.Á.)

* Correspondence: emf@fct.unl.pt (E.F.); rm@uninova.pt (R.M.); Tel.: +351-212948562 (E.F. \& R.M.)

\begin{abstract}
The degradation of organic pollutants in wastewaters assisted by oxide semiconductor nanostructures has been the focus of many research groups over the last decades, along with the synthesis of these nanomaterials by simple, eco-friendly, fast, and cost-effective processes. In this work, porous zinc oxide $(\mathrm{ZnO})$ nanostructures were successfully synthesized via a microwave hydrothermal process. A layered zinc hydroxide carbonate (LZHC) precursor was obtained after $15 \mathrm{~min}$ of synthesis and submitted to different calcination temperatures to convert it into porous $\mathrm{ZnO}$ nanostructures. The influence of the calcination temperature $\left(300,500\right.$, and $\left.700{ }^{\circ} \mathrm{C}\right)$ on the morphological, structural, and optical properties of the $\mathrm{ZnO}$ nanostructureswas investigated. All $\mathrm{ZnO}$ samples were tested as photocatalysts in the degradation of rhodamine B (RhB) under UV irradiation and natural sunlight. All samples showed enhanced photocatalytic activity under both light sources, with $\mathrm{RhB}$ being practically degraded within $60 \mathrm{~min}$ in both situations. The porous $\mathrm{ZnO}$ obtained at $700{ }^{\circ} \mathrm{C}$ showed the greatest photocatalytic activity due to its high crystallinity, with a degradation rate of 0.091 and $0.084 \mathrm{~min}^{-1}$ for UV light and sunlight, respectively. These results are a very important step towards the use of oxide semiconductors in the degradation of water pollutants mediated by natural sunlight.
\end{abstract}

Keywords: ZnO; porous nanostructures; zinc hydroxide carbonate; hydrothermal synthesis; microwave; sunlight photocatalysis

\section{Introduction}

The degradation of organic pollutants present in wastewater has developed into a topic of great importance, and has become the focus of many research fields. The organic dyes and compounds used in various industries (such as paper, textile, cosmetic, pharmaceutical, and plastics) lead to contaminated wastewaters that may have harmful effects in aqueous ecosystems and, therefore, on human health [1-3]. As such, many researchers have been looking to low-cost semiconductor oxides for the degradation of these pollutants through photocatalysis treatment processes.

Zinc oxide $(\mathrm{ZnO})$ has emerged as a promising photocatalyst due to its unique properties, such as its direct and wide bandgap of $3.37 \mathrm{eV}$ and its high exciton binding energy of $60 \mathrm{meV}$, as well as its nontoxicity, chemical stability, abundance in nature, and low cost [4]. However, $\mathrm{ZnO}$ is limited in its use as a photocatalyst due to the fast recombination rate of photogenerated carriers, its very poor response to visible light, and photocorrosion in aqueous solution under UV irradiation $[5,6]$. Nonetheless, there are different methods to improve the photocatalytic efficiency of $\mathrm{ZnO}$ (mainly under visible light [7]), including 
changing the $\mathrm{ZnO}$ morphology at the nanoscale [8,9], introducing/controlling bulk and surface defects $[10,11]$, coupling $\mathrm{ZnO}$ with other materials [12-15], and doping with metal or nonmetal ions [16-18]. However, it is not an easy task to compare the photocatalytic performance between works using different $\mathrm{ZnO}$ materials, since the experimental setup differs greatly from work to work [19-23]. Experimental parameters, such as irradiation light intensity and wavelength, photocatalyst properties and amounts, pollutant species or models, pollutant concentrations and solution volumes, and the relative position and configuration of the photocatalytic reactor to the light source have a great influence on the photocatalytic performance of the tested nanomaterials [24]. Therefore, it would only be possible to correctly compare $\mathrm{ZnO}$ nanomaterials as photocatalysts among works wherein similar experimental conditions are employed.

$\mathrm{ZnO}$ nanostructures can be produced through a variety of synthesis methods, such as electrodeposition [25], chemical bath deposition [26], chemical vapor deposition [27], and solvothermal [28] or hydrothermal $[29,30]$ synthesis, either by conventional or microwaveassisted heating [31-35]. Microwave-assisted hydrothermal/solvothermal synthesis represents an attractive synthesis method when compared to conventional heating due to its high reaction rate, since microwave radiation is absorbed by the species present in the reaction medium, which results in a homogeneous and rapid volumetric heating [35-37]. Depending on the precursors used and their concentrations, the selected solvents, and the $\mathrm{pH}$ of the solution, $\mathrm{ZnO}$ can be easily synthesized into several morphologies with high specific surface areas, such as nanorods, quantum dots, nanoplates, nanoneedles, nanotubes, nanoflowers, nanobelts, and nanowires [38-43].

Among $\mathrm{ZnO}$ nanomaterials, porous nanostructures with nanoscale thicknesses have received special attention due to their large specific surface area, which can enhance their performance in numerous applications [44-49]. Porous $\mathrm{ZnO}$ nanostructures can be obtained by the thermal decomposition of layered zinc hydroxide (LZH) materials [20]. LZHs are composed of positively charged zinc hydroxyl layers intercalated by anions and water molecules [50]. In particular, LZHs intercalated by carbonate ions (LZHC) are a promising precursor material to obtain porous $\mathrm{ZnO}$ nanostructures [20,51-54]. LZHC is typically obtained by hydrothermal methods with the desired morphology and then converted into porous $\mathrm{ZnO}$ nanostructures via calcination at high temperatures [55]. During thermal decomposition, the LZHC precursor releases gaseous molecules and, consequently, the original structure contracts and pores are formed throughout the materials [20]. In a previous work from our group [56], the application of porous $\mathrm{ZnO}$ nanostructures in nanogenerators via microwave assisted hydrothermal synthesis and calcination of a LZHC precursor was demonstrated.

In this work, porous $\mathrm{ZnO}$ nanostructures assembled into 3D hierarchical structures were obtained following the same procedure as in our previous work [56]. However, in this study, the LZHC precursor was calcinated at different temperatures and the influence of the calcination temperature on the final products was investigated. The produced porous $\mathrm{ZnO}$ nanostructures were tested as photocatalysts in the degradation of rhodamine $\mathrm{B}$ $(\mathrm{RhB})$ under UV and sunlight irradiation. Other authors have also studied the application of 3D hierarchical $\mathrm{ZnO}$ structures for the degradation of RhB under UV light and/or solar light $[19,20,22,23,57]$. However, the reported works typically employ conventional hydrothermal methods that take long periods of time and dope $\mathrm{ZnO}$ with other elements to increase its photocatalytic efficiency. For instance, Haibo et al. [23] synthesized carbondoped $\mathrm{ZnO}$ foam-like 3D structures via a hydrothermal method and tested them under natural sunlight. These authors obtained $98 \% \mathrm{RhB}$ degradation after 25 min using a catalyst concentration of $1 \mathrm{~g} \mathrm{~L}^{-1}$ and a RhB solution concentration of $5 \mathrm{mg} \mathrm{L}^{-1}$. Liu et al. [20] have also doped porous $\mathrm{ZnO}$ nanostructures with carbon by hydrothermal method for the photodegradation of $\mathrm{RhB}$ under visible light $(\lambda>420 \mathrm{~nm})$, obtaining $>90 \% \mathrm{RhB}$ degradation after $80 \mathrm{~min}$ using $5 \mathrm{~g}$ of catalyst per liter of RhB solution $\left(10 \mathrm{mg} \mathrm{L}^{-1}\right)$.

To the best of our knowledge, this is the first work to report the high photocatalytic efficiency of porous $\mathrm{ZnO}$ nanostructures synthesized by microwave hydrothermal method 
under UV and natural sunlight irradiation, where RhB was almost completely degraded within only $60 \mathrm{~min}$ of UV and sunlight exposure. These results are of great significance, as they demonstrate (along with our previous work [56]) the multifunctionality of porous $\mathrm{ZnO}$ nanostructures synthesized by a facile, fast, green, and low-cost hydrothermal method assisted by microwave irradiation.

\section{Materials and Methods}

\subsection{Synthesis and Characterization of Porous $\mathrm{ZnO}$ Nanostructures}

As reported in our previous work [56], the fabrication process of porous $\mathrm{ZnO}$ nanostructures can be divided into two steps. Firstly, a LZHC precursor is synthesized via hydrothermal method assisted by microwave irradiation. Secondly, the LZHC is calcinated at high temperatures where it turns into porous $\mathrm{ZnO}$ nanostructures. Briefly, for the synthesis of $\mathrm{LZHC}$, an aqueous solution with $0.05 \mathrm{M}$ of zinc nitrate hexahydrate $\left(\mathrm{Zn}\left(\mathrm{NO}_{3}\right)_{2} \cdot 6 \mathrm{H}_{2} \mathrm{O}\right.$, Sigma-Aldrich 98\%, Sigma-Aldrich, St. Louis, MO, USA) and $0.25 \mathrm{M}$ of urea $\left(\mathrm{CH}_{4} \mathrm{~N}_{2} \mathrm{O}\right.$, Sigma-Aldrich 99.0-100.5\%, Sigma-Aldrich, St. Louis, MO, USA) was prepared. The synthesis was carried out in a CEM Discovery SP microwave (CEM, Matthews, NC, USA) at $140{ }^{\circ} \mathrm{C}$ for $15 \mathrm{~min}$ under a power of $100 \mathrm{~W}$. The resulting LZHC powder was washed with deionized water and isopropanol and dried in air at room temperature for $48 \mathrm{~h}$. The dried LZHC was then calcinated in air in a muffle furnace (Nabertherm $\mathrm{GmbH}$, Lilienthal, Germany) at 300,500 , and $700{ }^{\circ} \mathrm{C}$ for $2 \mathrm{~h}$ with a heating rate of $250{ }^{\circ} \mathrm{C} \mathrm{h}^{-1}$.

$\mathrm{X}$-ray diffraction (XRD) was carried out to evaluate the crystallinity of the produced $\mathrm{ZnO}$ nanostructures using a PANalytical's X'Pert PRO MRD X-ray diffractometer (PANalytical B.V., Almero, The Netherlands), with a monochromatic $\mathrm{Cu} \mathrm{K} \alpha$ radiation source with a wavelength of $1.540598 \AA$. XRD measurements were performed with a scanning step size of $0.016^{\circ}$ from 10 to $90^{\circ}(2 \theta)$, with a scanning step size of $0.016^{\circ}$. Scanning electron microscopy (SEM) was used to evaluate the morphology of the calcinated $\mathrm{ZnO}$ products in a Carl Zeiss AURIGA CrossBeam FIB-SEM workstation equipped with an Oxford X-ray Energy Dispersive Spectrometer (Carl Zeiss Microscopy GmbH, Oberkochen, Germany). The apparent specific surface area was determined by employing the Brunauer-Emmet-Teller (BET) method to the adsorption isotherms obtained from nitrogen gas adsorption at $77 \mathrm{~K}$ in an adsorption apparatus (ASAP 2010 Micromeritics, Norcross, GA, USA), where the samples were degassed beforehand at $150{ }^{\circ} \mathrm{C}$ in vacuum.

Raman spectroscopy measurements of the calcinated $\mathrm{ZnO}$ products were performed in a Renishaw inVia Reflex micro-Raman spectrometer (Renishaw plc, Wotton-underEdge, UK) equipped with an air-cooled CCD detector and a HeNe laser operating at $50 \mathrm{~mW}$ of $532 \mathrm{~nm}$ laser excitation. The spectral resolution of the spectroscopic system was $0.3 \mathrm{~cm}^{-1}$. The laser beam was focused with a $50 \times$ Leica objective lens (N Plan EPI, Leica Microsystems, Wetzlar, Germany) with a numerical aperture of 0.75 . An integration time of two scans ( $30 \mathrm{~s}$ each) was used for all measurements to reduce the random background noise induced by the detector without significantly increasing the acquisition time. The intensity of the incident laser was $0.5 \mathrm{~mW}$. All spectra were obtained in triplicate for each sample at room temperature in the wavelength range between 70 and 17,800 $\mathrm{nm}$. Triplicates of all samples were performed. All the raw data were collected digitally with Wire 5.0 software for processing, including cosmic ray removal, noise reduction, and baseline. Fitting with Lorentzian was performed in order to identify the different vibrational bands. Fourier transform infrared (FTIR) spectroscopy measurements were carried out using an attenuated total reflectance (ATR) sampling accessory (Smart iTR, ThermoFisher Scientific Inc., Waltham, MA, USA) equipped with a single bounce diamond crystal on a Thermo Nicolet 6700 spectrometer (ThermoFisher Scientific Inc., Waltham, MA, USA). The FTIR spectra were acquired with a $45^{\circ}$ incident angle in the range between 4000 and $500 \mathrm{~cm}^{-1}$ and with a $4 \mathrm{~cm}^{-1}$ resolution.

Diffuse reflectance measurements of the porous $\mathrm{ZnO}$ nanostructures were carried out using a PerkinElmer lambda 950 UV/VIS/NIR spectrophotometer (PerkinElmer, Waltham, MA, USA) with an integrating sphere with a $150 \mathrm{~mm}$ diameter internally coated with 
Spectralon. The reflectance spectra were obtained at room temperature from 350 to $800 \mathrm{~nm}$. A standard Spectralon reflector sample was used as a reference $(R=1.0)$ to calibrate the system.

The photoluminescence (PL) of the porous $\mathrm{ZnO}$ structures was evaluated using a PerkinElmer LS55 luminescence spectrometer (PerkinElmer, Waltham, MA, USA) equipped with a Xenon lamp as an excitation source. The PL measurements were performed at room temperature, from 350 to $700 \mathrm{~nm}$, using an excitation wavelength of $254 \mathrm{~nm}$ and a cut-off filter of $350 \mathrm{~nm}$.

\subsection{Characterization of Porous $\mathrm{ZnO}$ Nanostructures as Photocatalysts}

The photocatalytic activity of the porous $\mathrm{ZnO}$ nanostructures calcinated at different temperatures under UV radiation was characterized by the degradation of rhodamine $\mathrm{B}(\mathrm{RhB})$ from Sigma-Aldrich, at room temperature. For this purpose, $25 \mathrm{mg}$ of each sample were dispersed into $50 \mathrm{~mL}$ of $\mathrm{RhB}$ aqueous solution $\left(4 \mathrm{mg} \mathrm{L}^{-1}\right)$ and then stirred for $30 \mathrm{~min}$ in the dark to establish adsorption-desorption equilibrium. The solutions with the dispersed $\mathrm{ZnO}$ nanostructures were then exposed to UV irradiation using three mercury lamps (model HNSL from Osram Puritec) with a power of $95 \mathrm{~W}$ each, a wavelength of $254 \mathrm{~nm}$, and a total UV light intensity of $35 \mathrm{~mW} \mathrm{~cm}^{-2}$. The solution vessels were placed at $27.5 \mathrm{~cm}$ from the UV light source. The absorbance spectra of the solutions were recorded using a PerkinElmer lambda 950 UV/VIS/NIR spectrophotometer with intervals of $15 \mathrm{~min}$ until $60 \mathrm{~min}$ of UV exposure to investigate the photocatalytic performance of the produced samples on the degradation of RhB. After each UV exposure, $4 \mathrm{~mL}$ of the RhB solutions with the dispersed nanostructures were collected after centrifugation for the absorbance measurement and then returned to the container for further UV exposition. The porous $\mathrm{ZnO}$ nanostructures were also tested as photocatalysts under natural sunlight around midday for a total exposure time of $60 \mathrm{~min}$. Sunlight intensity was found to be around $89 \mathrm{~mW} \mathrm{~cm}^{-2}$ ( 0.89 sun) during the photocatalysis experiments using a solar power meter from Sciencetech (Sciencetech-Inc, London, ON, Canada). Here, the absorbance spectra of the aqueous $\mathrm{RhB}$ solutions with the dispersed photocatalysts were recorded with intervals of $15 \mathrm{~min}$ until $60 \mathrm{~min}$ of sunlight exposure. As before, after each sunlight exposure, $4 \mathrm{~mL}$ of the tested solutions were collected after centrifugation for the absorbance measurement and then returned to the container for further sunlight exposure.

\section{Results and Discussion}

\subsection{Characterization of the Porous $\mathrm{ZnO}$ Nanostructures}

Porous $\mathrm{ZnO}$ nanostructures were produced via the calcination of a LZHC precursor. LZHC was synthesized by hydrothermal method assisted by microwave irradiation and it was fully characterized in our previous report [56]. After the calcination process at 300,500 , and $700{ }^{\circ} \mathrm{C}$, the LZHC precursor was successfully converted into porous $\mathrm{ZnO}$ nanostructures, which can be inferred from the X-ray diffractograms of the obtained samples, shown in Figure 1a. All the peaks in the diffractograms correspond to the hexagonal wurtzite $\mathrm{ZnO}$ structure (ICDD 36-1451). No characteristic peaks from any other impurities were detected, indicating that the LZHC precursor was completely converted into $\mathrm{ZnO}$. Additionally, the diffraction peaks become narrower with increasing calcination temperature, leading to an increase in the crystallite size of the $\mathrm{ZnO}$ samples. SEM images of the porous $\mathrm{ZnO}$ products are presented in Figure $1 \mathrm{~b}$ with different magnifications. The low magnification images show that the $\mathrm{ZnO}$ nanomaterials are assembled to hierarchically form flower-like 3D structures, as observed in our previous work [56]. However, when observing the high magnification SEM images, it is possible to see that the $\mathrm{ZnO}$ nanoplates present a porous structure with serrate edges, where higher calcination temperatures result in larger pores with a wider size distribution. 
(a)

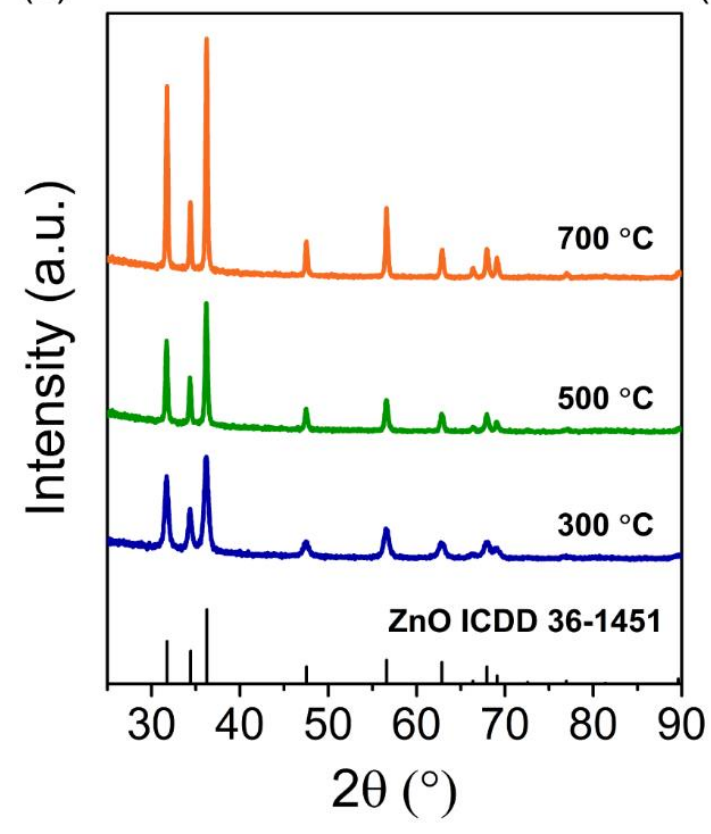

(b)
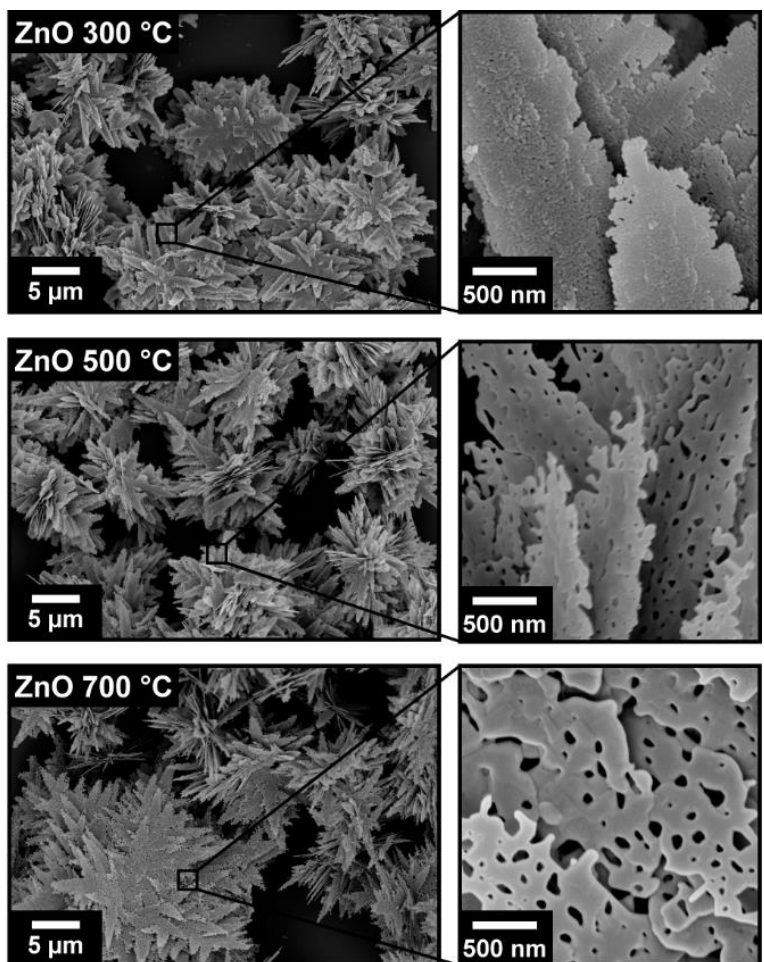

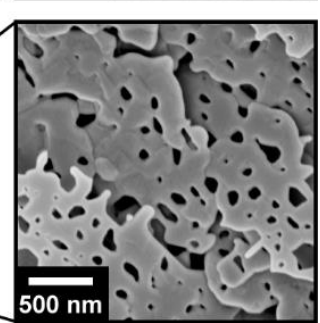

Figure 1. (a) XRD diffractograms and (b) SEM images of porous $\mathrm{ZnO}$ nanostructures synthesized via the hydrothermal method (assisted by microwave irradiation) and calcinated at 300,500 , and $700{ }^{\circ} \mathrm{C}$.

The porous $\mathrm{ZnO}$ nanostructures were further investigated by $\mathrm{N}_{2}$ adsorption/desorption measurements. The resulting adsorption isotherm curves are presented in Figure S1. The obtained isotherm curves and hysteresis loop can be ascribed to type IV, according to the IUPAC classification [58], which indicates the presence of mesopores (2 to $50 \mathrm{~nm}$ in size) [20]. When the calcination temperature increases, the hysteresis loop shifts to higher relative pressures and the loop area decreases, resulting in smaller specific surface areas and larger pores [20,58]. Using Brunauer-Emmett-Teller (BET) analysis, it was found that $\mathrm{ZnO}$ nanostructures calcinated at $300{ }^{\circ} \mathrm{C}$ have the highest specific surface area of $38.51 \mathrm{~m}^{2} \mathrm{~g}^{-1}$, while calcination temperatures of 500 and $700{ }^{\circ} \mathrm{C}$ resulted in specific surface areas of 11.68 and $6.41 \mathrm{~m}^{2} \mathrm{~g}^{-1}$, respectively. From the SEM images in Figure $1 \mathrm{~b}$, it appears that the $300{ }^{\circ} \mathrm{C}$ calcination temperature originates smaller mesopores in higher concentration and narrower size distribution. However, with increasing temperature, the smaller pores start to coalesce into larger ones, which leads to $\mathrm{ZnO}$ nanoplates with larger mesopores with a higher size distribution.

The normalized Raman spectra of the porous $\mathrm{ZnO}$ nanostructures are shown in Figure 2a. In $\mathrm{ZnO}$, the lattice optical phonons at the point $\Gamma$ of the Brillouine zone is given by the optical symmetry modes $A_{1}+2 B_{1}+E_{1}+2 E_{2}$ [31,59]. The active Raman modes include the modes $A_{1}, E_{1}$, and $E_{2}$, with $A_{1}$ and $E_{1}$ also being infrared active and splitting into longitudinal-optical (LO) and transversal-optical (TO) components [60]. Based on the Raman spectra in Figure 2a, the two most intense peaks are located at 98 and $437 \mathrm{~cm}^{-1}$ and are attributed to the $\mathrm{E}_{2}{ }^{\mathrm{High}}$ and $\mathrm{E}_{2}{ }^{\mathrm{Low}}$ optical modes, respectively, which are characteristic of the wurtzite hexagonal of $\mathrm{ZnO}$ [61]. The peak at $380 \mathrm{~cm}^{-1}$ is associated with the $\mathrm{A}_{1}$ (TO) mode, while the peak at $409 \mathrm{~cm}^{-1}$ is related to the $\mathrm{E}_{1}$ (TO) mode. The band around $580 \mathrm{~cm}^{-1}$ is reported to be a superposition of the $A_{1}$ (LO) mode at $574 \mathrm{~cm}^{-1}$ and the $\mathrm{E}_{1}(\mathrm{LO})$ mode at $583 \mathrm{~cm}^{-1}$ [62]. The porous $\mathrm{ZnO}$ nanostructures calcinated at $300{ }^{\circ} \mathrm{C}$ show an intense band at low wavenumbers, with two prominent peaks at 80 and $115 \mathrm{~cm}^{-1}$. These two peaks are present in the Raman spectrum of the LZHC precursor shown in Figure S2, suggesting an incomplete pyrolysis of the precursor into $\mathrm{ZnO}$ for calcination temperatures of $300^{\circ} \mathrm{C}$. Higher calcination temperatures result 
in more defined and narrower peaks, which are an indicator of samples with higher crystallinity [63,64], as corroborated by the X-ray diffractograms in Figure 1a. Moreover, Y. Song et al. [65] demonstrated that the absorption band from around 80 to $190 \mathrm{~cm}^{-1}$ may be related to interstitial zinc defects, whereas the intensity of the band around $580 \mathrm{~cm}^{-1}$ may be attributed to oxygen vacancies. In addition, the band around $535 \mathrm{~cm}^{-1}$ in the Raman spectra has been assigned to $\mathrm{B}_{1}{ }^{\text {high }}$ mode. Although this mode is Raman inactive, its appearance may occur due to modification of the translational crystal symmetry induced by defects or impurities in the $\mathrm{ZnO}$ structure $[59,66]$.
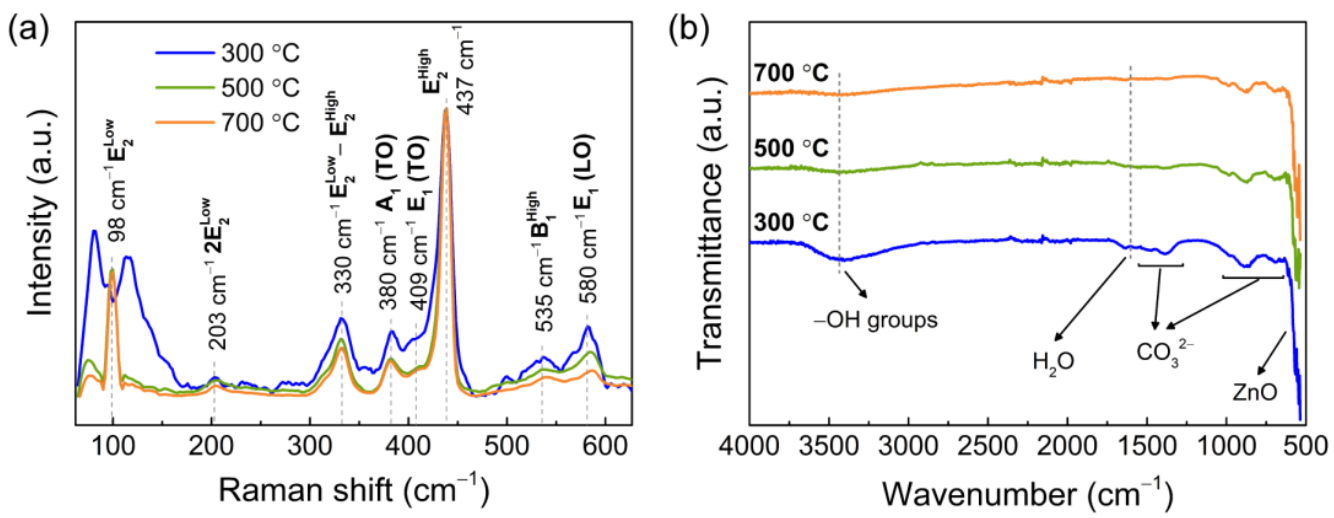

Figure 2. (a) Raman spectra and (b) FTIR spectra of porous ZnO nanostructures calcinated at 300, 500 , and $700{ }^{\circ} \mathrm{C}$.

The FTIR spectra of the porous $\mathrm{ZnO}$ nanostructures calcinated at different temperatures are displayed in Figure $2 \mathrm{~b}$. The strong absorbance band from $632 \mathrm{~cm}^{-1}$ to lower wavenumbers is characteristic of wurtzite $\mathrm{ZnO}$, which usually presents a strong infrared peak around $443 \mathrm{~cm}^{-1}$ that cannot be detected with the used FTIR spectrometer. This absorption region is assigned to the stretching vibration mode of $\mathrm{Zn}-\mathrm{O}$ [67-69]. The bands from 1570 to $1390 \mathrm{~cm}^{-1}$ as well as the bands from 1100 to $700 \mathrm{~cm}^{-1}$ are attributed to the presence of $\mathrm{CO}_{3}{ }^{2-}$ from the LZCH precursor [70-72]. The small absorption band found at $1640 \mathrm{~cm}^{-1}$ is associated with the bending mode of the water molecule [73,74]. The broad band around $3400 \mathrm{~cm}^{-1}$ is attributed to the vibration mode of hydroxyl groups $(-\mathrm{OH})$, which are known to be actively adsorptive sites [75]. However, this broad band decreases with calcination temperature, alongside the $\mathrm{CO}_{3}{ }^{2-}$ absorption bands, which result from the incomplete pyrolysis of the LZHC precursor. As such, as shown in Raman spectra and the $\mathrm{X}$-ray diffractograms, a calcination temperature of $700{ }^{\circ} \mathrm{C}$ results in purer and more crystalline $\mathrm{ZnO}$ nanostructures.

The UV-Vis diffuse reflectance of the produced $\mathrm{ZnO}$ samples is presented in Figure $3 \mathrm{~b}$. A slight blue shift in the absorption edge is observed for higher calcination temperatures. This shift occurs due to the increase in the crystallinity of $\mathrm{ZnO}$ with increasing temperature, as shown in Figure 1a.

As shown through Raman and FTIR analyses, the presence of bulk defects is more significant in the porous $\mathrm{ZnO}$ nanostructures calcinated at 300 and $500{ }^{\circ} \mathrm{C}$. These defects create extra levels between the valence and conduction band $[19,76]$ that lead to a shift of the absorption edge to longer wavelengths and increase the absorption ability in the visible range, indicating that these nanostructures may have a good photocatalytic performance under visible light [77].

The optical band gap $E_{g}$ was calculated by applying the Kubelka-Munk (K-M) method to the reflectance $(R)$ data [76]. The K-M method is based on the following equation:

$$
F(R)=\frac{(1-R)^{2}}{2 R}
$$



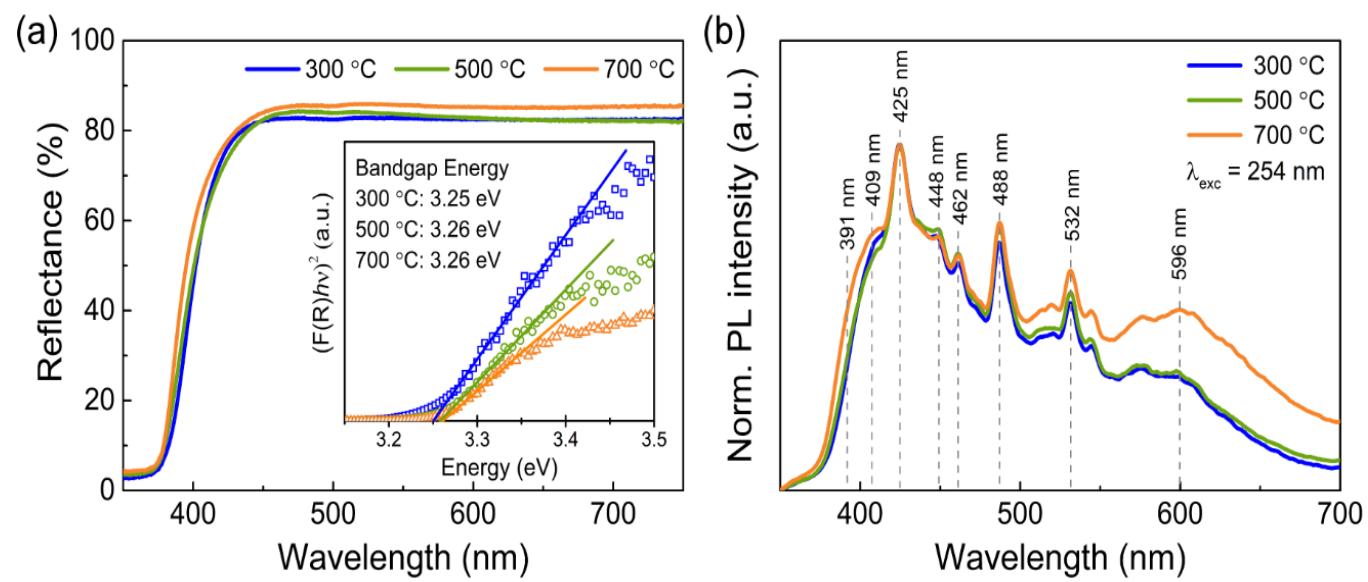

Figure 3. (a) Reflectance spectra of the porous $\mathrm{ZnO}$ nanostructures calcinated at 300,500 , and $700{ }^{\circ} \mathrm{C}$ with an inset graphic showing the obtained bandgap energy for each calcination temperature through the K-M function. (b) Photoluminescence spectra of the porous $\mathrm{ZnO}$ samples measured with an excitation wavelength of $254 \mathrm{~nm}$.

The K-M function $(F(R))$ is proportional to the absorption coefficient $(\alpha)$. Therefore, by considering the Tauc relation, the following expressions can be obtained [78]:

$$
\begin{gathered}
F(R) \propto \alpha \propto \frac{\left(h v-E_{g}\right)^{1 / n}}{h v} \\
(F(R) h v)^{n}=A\left(h v-E_{g}\right)
\end{gathered}
$$

where $A$ is a constant and $n$ is equal to 2 for semiconductors with direct allowed transitions [79]. As shown by the inset graph in Figure 3a, the value of $E_{g}$ can be determined by extrapolating the linear part of the function curve with the energy axis. The estimated bandgap energies are 3.25, 3.26, and $3.26 \mathrm{eV}$ for the $\mathrm{ZnO}$ nanostructures obtained at 300, 500 , and $700{ }^{\circ} \mathrm{C}$, respectively, which is consistent with the observed slight shift in the absorption edge and with the values reported in the literature [20,77].

The photoluminescence (PL) spectra of the porous $\mathrm{ZnO}$ nanostructures are presented in Figure $3 \mathrm{~b}$. Although the origin of $\mathrm{PL}$ in $\mathrm{ZnO}$ is typically assigned to the recombination of the photoinduced carriers and the intrinsic defects of this metal oxide's nanostructures, a consensus concerning the exact origin of the defect-related visible PL of $\mathrm{ZnO}$ has not yet been reached. Indeed, numerous hypotheses have been proposed to explain the emission in this region over the last decades [62,80-84]. Nevertheless, it is commonly accepted that the nature of visible $\mathrm{PL}$ in $\mathrm{ZnO}$ revolves around intrinsic defects in the $\mathrm{ZnO}$ matrix, such as interstitial zinc and oxygen $\left(\mathrm{Zn}_{\mathrm{i}}\right.$ and $\left.\mathrm{O}_{\mathrm{i}}\right)$, antisite oxygen $\left(\mathrm{O}_{\mathrm{Zn}}\right)$, and oxygen and zinc vacancies $\left(\mathrm{V}_{\mathrm{O}}\right.$ and $\left.\mathrm{V}_{\mathrm{Zn}}\right)$ [85]. In micro- and nanostructured $\mathrm{ZnO}$, the PL emission is widely influenced by the surface and interface properties and, therefore, the synthesis method plays an important role in the resulting PL signal [86-89]. If the surface-to-volume ratio of $\mathrm{ZnO}$ nanostructures is high, then the PL spectra will mostly be influenced by surfacerelated defects, where new emission bands may arise and dominate over the bulk-related luminescence [81]. Therefore, by controlling the distribution of surface vs bulk defects, it is possible to tailor the material's PL properties.

The normalized PL spectra of the porous $\mathrm{ZnO}$ nanostructures, shown in Figure $3 b$, depict several emission bands in the blue (400-490 nm), green $(500-550 \mathrm{~nm})$, and yelloworange $(\sim 600 \mathrm{~nm})$ regions of the spectra. From Figure $3 b$, it is evident that the blue emission bands are more intense than the green and yellow-orange bands. Figure S3a in Supplementary Materials shows the deconvolution of one of the spectra into several Gaussian components, and the values of the main Gaussian peaks are marked in Figure 3b. The component centered around $391 \mathrm{~nm}$ is usually attributed to the recombination of free excitons formed upon excitation [80]. $\mathrm{ZnO}$ has a free binding energy $\left(E_{X}\right)$ of around 
$60 \mathrm{meV}[59,90]$ and, therefore, the energy of the radiative recombination would be equal to $E_{g}-E_{X}$. By taking into account the $E_{g}$ value calculated for $\mathrm{ZnO}(\sim 3.25-3.26 \mathrm{eV})$, this emission would have a value around $3.2 \mathrm{eV}(\sim 388 \mathrm{~nm})$, which is close to the observed emission band at $391 \mathrm{~nm}$. The blue emissions between 409 and $488 \mathrm{~nm}$ have been assigned by several authors to the transitions between $Z n_{i}$ and extended $Z n_{i}$ levels and the valence band (VB) $[59,62,80,84,89] . \mathrm{Zn}_{\mathrm{i}}$ defects form a shallow donor level and many PL studies have considered the location of this level at $0.22 \mathrm{eV}$ below the conduction band (CB) $[84,89,91,92]$. The transition from this level to the VB would originate an emission at around $410 \mathrm{~nm}$, which is in good accordance with the observed band at $409 \mathrm{~nm}$ in Figure 3b. In particular, Zeng et al. [84] demonstrated that the violet and blue emissions between 415 and $488 \mathrm{~nm}$ of $\mathrm{ZnO}$ nanoparticles originate from transitions from $\mathrm{Zn}_{\mathrm{i}}$ and extended $\mathrm{Zn}_{\mathrm{i}}$ levels to the $\mathrm{VB}$, which is in good agreement with the observed emission bands in the same region in this work.

The green PL emission observed around $532 \mathrm{~nm}$ has been associated with different defects in $\mathrm{ZnO}$ and, as such, it is considered one of the most controversial emission bands of $\mathrm{ZnO}$. Many authors have attributed this emission to the transition between the $\mathrm{CB}$ and $\mathrm{Zn}_{\mathrm{i}}$ levels to the $V_{O}$ defect level $[59,62,91,93-96]$, whereas other works suggest that it is in fact the transitions involving $\mathrm{V}_{\mathrm{Zn}}$ defects that generate the green $\mathrm{PL}$ in $\mathrm{ZnO}[83,97-100]$. Despite the lack of consensus about the origin of the green emission, it has been demonstrated by many groups that this emission is mostly governed by surface defects $[62,86,88,101]$, meaning that $\mathrm{ZnO}$ nanostructures with high specific surface areas will most likely present strong emissions in this region, as was observed for the porous $\mathrm{ZnO}$ nanostructures in this work.

Regarding the yellow emission observed around $596 \mathrm{~nm}$, it has been reported that it may originate from the transition from the $\mathrm{CB}$ or $\mathrm{Zn}_{\mathrm{i}}$ to the $\mathrm{O}_{\mathrm{i}}$ defect level, which has been placed at around $2.28 \mathrm{eV}$ below the CB [81,86,88,102-104], which is in good agreement with the yellow-orange PL in this work. It has been suggested that annealing at high temperatures in an oxygen-rich environment increases the intensity of this emission [86,103], which may explain the higher intensity of this PL band for the porous $\mathrm{ZnO}$ nanostructures calcinated at $700{ }^{\circ} \mathrm{C}$ in air.

In summary, it should be noted that the PL emission usually observed for $\mathrm{ZnO}$ is composed of several emission bands, as suggested in Figure S3a, which indicates that distinct transitions involving different defect levels may contribute to the PL emission in the same region of the spectrum. Therefore, a straightforward PL analysis is not possible in most cases and complementary characterization techniques are needed to infer the origin of each observed PL band. In spite of this, the PL signal acquired in this work for all of the produced porous $\mathrm{ZnO}$ nanostructures indicates that these materials can be excited with sub bandgap excitation energies, as proven by the PL spectra in Figure S3b, where the ZnO obtained at $700{ }^{\circ} \mathrm{C}$ presented visible PL emissions for different excitation wavelengths. These results show that these nanostructures can absorb light in the visible range and, therefore, they can be applied in visible light photocatalysis.

\subsection{Photocatalytic Activity of the Porous $\mathrm{ZnO}$ Nanostructures}

Rhodamine B is commonly used as a model dye contaminants in photocatalytic tests [24,105-109]. RhB is highly soluble in water and has an absorption peak in the visible range around $554 \mathrm{~nm}$, meaning that its degradation can be easily monitored using optical absorbance spectroscopy. As such, the UV photocatalytic activity of the porous $\mathrm{ZnO}$ nanostructures was evaluated from the intensity decrease of the maximum absorption peak of the RhB solution after UV light exposure. The absorbance spectra of RhB recorded at different degradation times for $\mathrm{ZnO}$ samples calcinated at 300, 500, and $700{ }^{\circ} \mathrm{C}$ are presented in Figure 4a. Based on these absorbance spectra, it can be observed that all tested calcination temperatures yielded very good degradation values after only $60 \mathrm{~min}$ of UV light exposure. Figure $4 \mathrm{~b}$ shows the ratio between the absorbance value at each exposure 
time, $C$, and the initial absorbance of the RhB solution, $C_{0}$. The degradation percentage can then be calculated using

$$
\text { Degradation }(\%)=\frac{\left(C_{0}-C\right)}{C_{0}} \times 100
$$
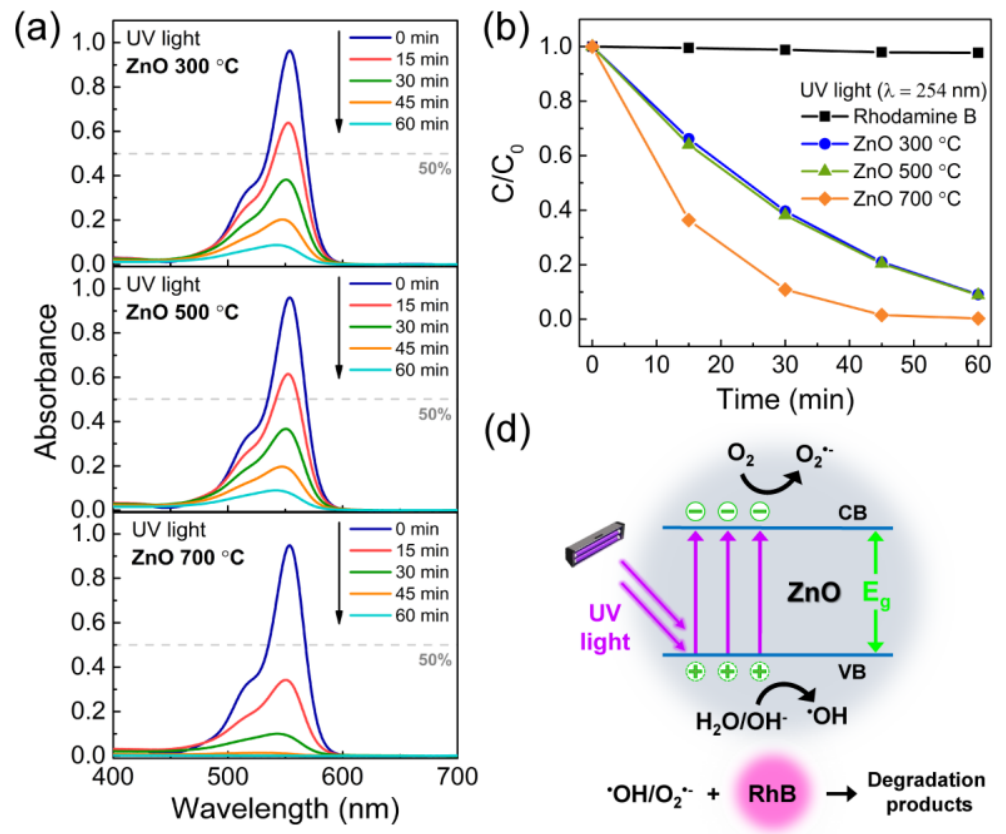

(d)
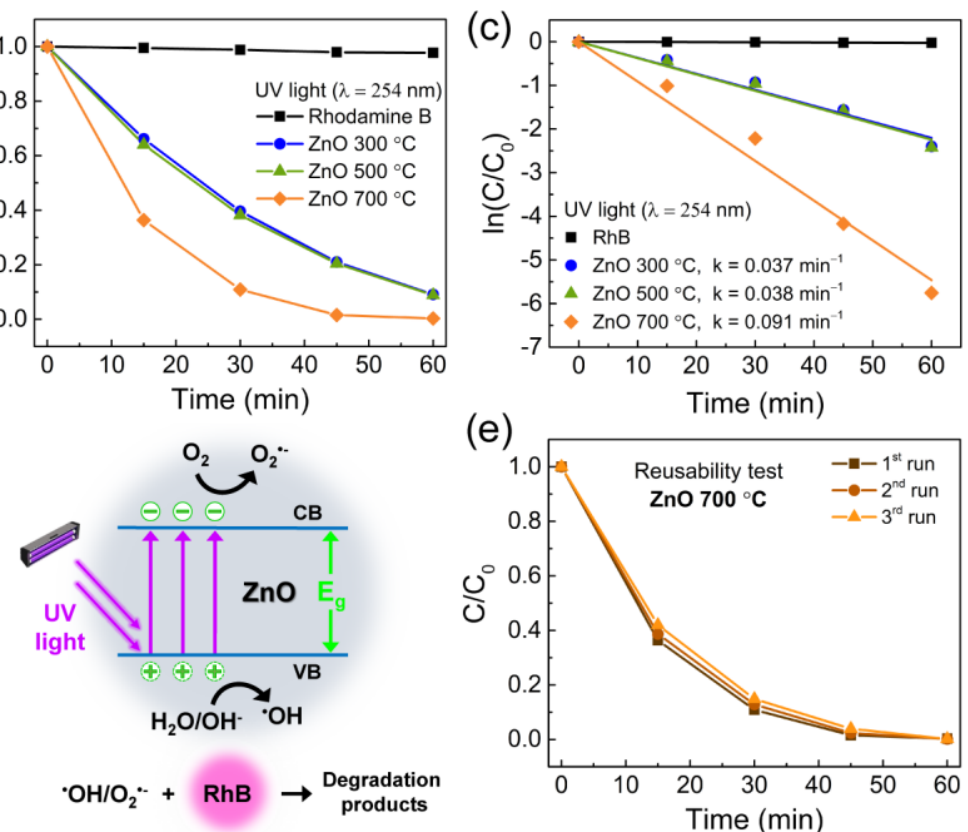

(e)

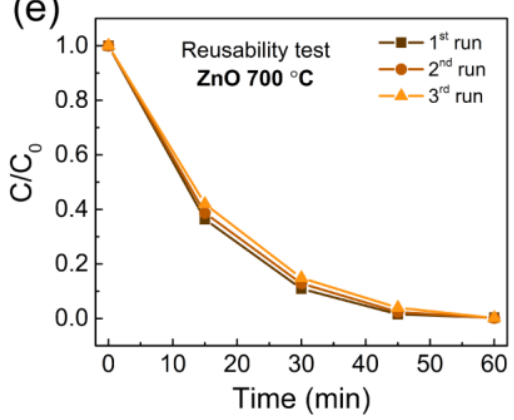

Figure 4. (a) Absorbance spectra of RhB recorded at different degradation times under UV irradiation for ZnO samples calcinated at 300,500 , and $700{ }^{\circ} \mathrm{C}$. (b) Degradation ratio $C / C_{0}$ of RhB vs. UV exposure time for all the produced porous $\mathrm{ZnO}$ samples. (c) $\ln \left(\mathrm{C} / \mathrm{C}_{0}\right)$ vs. UV exposure time and the resultant degradation rates $k$ for each tested sample. (d) UV light photocatalytic mechanism of $\mathrm{ZnO}$. (e) Reusability tests of the $\mathrm{ZnO}$ sample calcinated at $700{ }^{\circ} \mathrm{C}$ showing the degradation ratio $C / C_{0}$ for three photocatalytic runs.

The degradation percentage was found to increase with the calcination temperature, presenting values around $91 \%, 92 \%$, and $>99 \%$ for $\mathrm{ZnO}$ nanostructures calcinated at 300 , 500 , and $700{ }^{\circ} \mathrm{C}$, respectively. In addition to the visible absorbance spectra of $\mathrm{RhB}$, the efficiency of the photocatalytic process can also be evaluated by the constant rate $k$ of the process. This constant is given by the following pseudo first-order kinetics reaction equation, valid for pollutant concentrations in the millimolar range [110]:

$$
\ln \frac{C}{C_{0}}=k t
$$

Figure $4 \mathrm{c}$ shows the $\ln \left(C / C_{0}\right)$ curves of the $\mathrm{RhB}$ solution without and with the $\mathrm{ZnO}$ nanostructures for each UV exposure time. All the presented curves were linearly fitted to obtain the constant rate $k$ of the degradation process. $\mathrm{ZnO}$ nanostructures calcinated at $700{ }^{\circ} \mathrm{C}$ present a degradation rate around $0.091 \mathrm{~min}^{-1}$, whereas calcination temperatures of 300 and $500{ }^{\circ} \mathrm{C}$ result in similar degradation rates: 0.037 and $0.038 \mathrm{~min}^{-1}$, respectively.

The UV photocatalytic mechanism (Figure $4 \mathrm{~d}$ ) is based on the photogeneration of electron-hole $\left(\mathrm{e}^{-} / \mathrm{h}^{+}\right)$pairs in the semiconductor photocatalyst when exposed to UV light with energy close to that of the semiconductor bandgap. The photoinduced $\mathrm{e}^{-} / \mathrm{h}^{+}$pairs can recombine or migrate to the semiconductor surface and participate in a series of oxidationreduction reactions with adsorbed species. The photogenerated holes in the valence band can react with surface-bound hydroxyl groups $(-\mathrm{OH})$ and adsorbed water molecules to form hydroxyl radicals $\left({ }^{\bullet} \mathrm{OH}\right)$ [111]. On the other hand, electrons in the conduction band react with oxygen molecules to form superoxide radicals $\left(\mathrm{O}_{2}{ }^{\bullet-}\right)$ [112]. The $\mathrm{O}_{2}{ }^{\bullet-}$ species 
contribute to the formation of hydrogen peroxide that, together with ${ }^{\bullet} \mathrm{OH}$ radicals, leads to the degradation of the dyes [113].

There are several factors that influence the photocatalytic efficiency of semiconductors materials, including specific surface area, bandgap energy, morphology, crystallinity and crystal facets, surface and bulk defects, and nanoparticle size [114,115]. Even though the specific surface area plays an important role in the photocatalytic performance of nanostructures due to the large number of active adsorption sites, in the UV light experiments performed in this work high specific surface areas do not necessarily mean high photocatalytic efficiencies. In fact, the porous $\mathrm{ZnO}$ nanostructures calcinated at $700{ }^{\circ} \mathrm{C}$ show the highest degradation rate in spite of being the nanostructures with the lowest specific surface area. In this case, the high crystallinity of these $\mathrm{ZnO}$ nanostructures, as observed in Figure 1a, is the most critical factor influencing their photocatalytic activity. High crystallinities indicate a decrease in the relative concentration of bulk to surface defects [116]. Surface defects not only serve as adsorption sites but also as charge carrier traps, where the trapped carriers can then be transferred to the adsorbed species, which prevents the recombination of photogenerated $\mathrm{e}^{-} / \mathrm{h}^{+}$pairs $[19,117,118]$. On the other hand, bulk defects can act as recombination centers for the photogenerated carriers, leading to a significant decrease in photocatalytic activity [119]. As suggested by Liu et al. [62] and Hong et al. [120], this decrease is a compromise between the specific surface area and the concentration ratio of surface to bulk defects in a semiconductor that results in high photocatalytic activities. In this particular case, as it was also observed by Liu et al. [62], it is the high crystallinity and, consequently, the low relative ratio of bulk to surface defects that governs the photocatalytic efficiency of the produced porous $\mathrm{ZnO}$ nanostructures.

In the end, the porous $\mathrm{ZnO}$ nanostructures calcinated at $700{ }^{\circ} \mathrm{C}$ and tested as photocatalysts were washed with de-ionized water (followed by isopropanol) and centrifuged at $4500 \mathrm{rpm}$ for $5 \mathrm{~min}$. After drying at $60^{\circ} \mathrm{C}$ for $2 \mathrm{~h}$ in vacuum, these nanostructures were tested two more times for the degradation of $\mathrm{RhB}$ following the same experiment steps as before and keeping the same amount of powder in each run. Figure $4 \mathrm{e}$ shows the degradation ratio $C / C_{0}$ for the three photocatalytic runs. The porous $\mathrm{ZnO}$ nanostructures displayed very similar performances in the photodegradation of $\mathrm{RhB}$, thus demonstrating that they can be reused several times to degrade organic pollutants in water.

Figure 5a presents the absorbance spectra of the $\mathrm{RhB}$ solution with the dispersed $\mathrm{ZnO}$ catalysts under sunlight irradiation. The photocatalytic activity of the $\mathrm{ZnO}$ nanostructures under sunlight is similar to the one observed under UV light. Here, RhB was also practically degraded after 60 min of sunlight exposure, with $92 \%, 95 \%$, and $>99 \%$ of RhB being degraded by the porous $\mathrm{ZnO}$ nanostructures obtained at 300,500 , and $700{ }^{\circ} \mathrm{C}$, respectively. Figure $5 \mathrm{~b}$ shows the degradation ratio $C / C_{0}$ for the $\mathrm{RhB}$ solutions without and with the $\mathrm{ZnO}$ catalysts. From the calculated $\ln \left(C / C_{0}\right)$ curves in Figure $5 c$, the degradation rate $k$ was found to be slightly higher for the $\mathrm{ZnO}$ calcinated at 300 and $500{ }^{\circ} \mathrm{C}\left(0.040\right.$ and $0.046 \mathrm{~min}^{-1}$, respectively) when compared to the values determined for UV photocatalysis $\left(0.037\right.$ and $0.038 \mathrm{~min}^{-1}$, respectively), whereas the $k$ calculated for the $\mathrm{ZnO}$ produced at $700{ }^{\circ} \mathrm{C}\left(0.084 \mathrm{~min}^{-1}\right)$ decreased slightly compared to its value after UV exposure $\left(0.091 \mathrm{~min}^{-1}\right)$.

Under solar light irradiation, RhB undergoes two degradation processes that occur simultaneously: a photocatalytic process, where the decomposition of the dye occurs through the destruction of its chromophore structure, and a N-deethylation process [121-123]. Figure $5 \mathrm{~d}$ shows a schematic of both these processes. Like UV photocatalysis, if the semiconductor catalyst is able to absorb visible light, it will generate electron-hole $\left(\mathrm{e}^{-} / \mathrm{h}^{+}\right)$pairs. As explained before, the photoinduced carriers will originate ${ }^{\bullet} \mathrm{OH}$ and $\mathrm{O}_{2}{ }^{\bullet-}$ radicals from the adsorbed oxygen-rich molecules on the $\mathrm{ZnO}$ surface, which will in turn participate in the degradation of $\mathrm{RhB}$ in the solution. On the other hand, it has been reported that $\mathrm{RhB}$ molecules can be excited by visible light $[124,125]$. When these molecules are adsorbed on the $\mathrm{ZnO}$ surface and are excited by visible light, the excited $\mathrm{RhB}^{*}$ can inject electrons into the conduction band of $\mathrm{ZnO}$ followed by its conversion into cation radicals $\mathrm{RhB}^{\bullet+}$. Adsorbed oxygen molecules can, in turn, capture the injected electrons to yield ${ }^{\bullet} \mathrm{OH}$ and 
$\mathrm{O}_{2}{ }^{\bullet-}$ radicals. These radicals will then degrade both the created $\mathrm{RhB}^{\bullet+}$ cation radicals and the $\mathrm{RhB}$ molecules in the solution [126]. The $\mathrm{RhB}^{\bullet+}$ cation radicals can also be further decomposed into $\mathrm{N}$-deethylated products by hydrolysis or by reacting with $\mathrm{HO}_{2} \bullet / \mathrm{O}_{2}{ }^{\bullet-}$ radicals. The resulting $\mathrm{N}$-deethylated products are responsible for a gradual hypsochromic shift in the absorbance peak since the $\mathrm{N}$-deethylation of RhB is known to be a stepwise process $[77,78,127,128]$. This hypsochromic shift in the absorbance peak was not observed in Figure 5a, suggesting that the degradation of RhB through sunlight photocatalysis by the porous $\mathrm{ZnO}$ nanostructures is the predominant degradation route in these experiments.
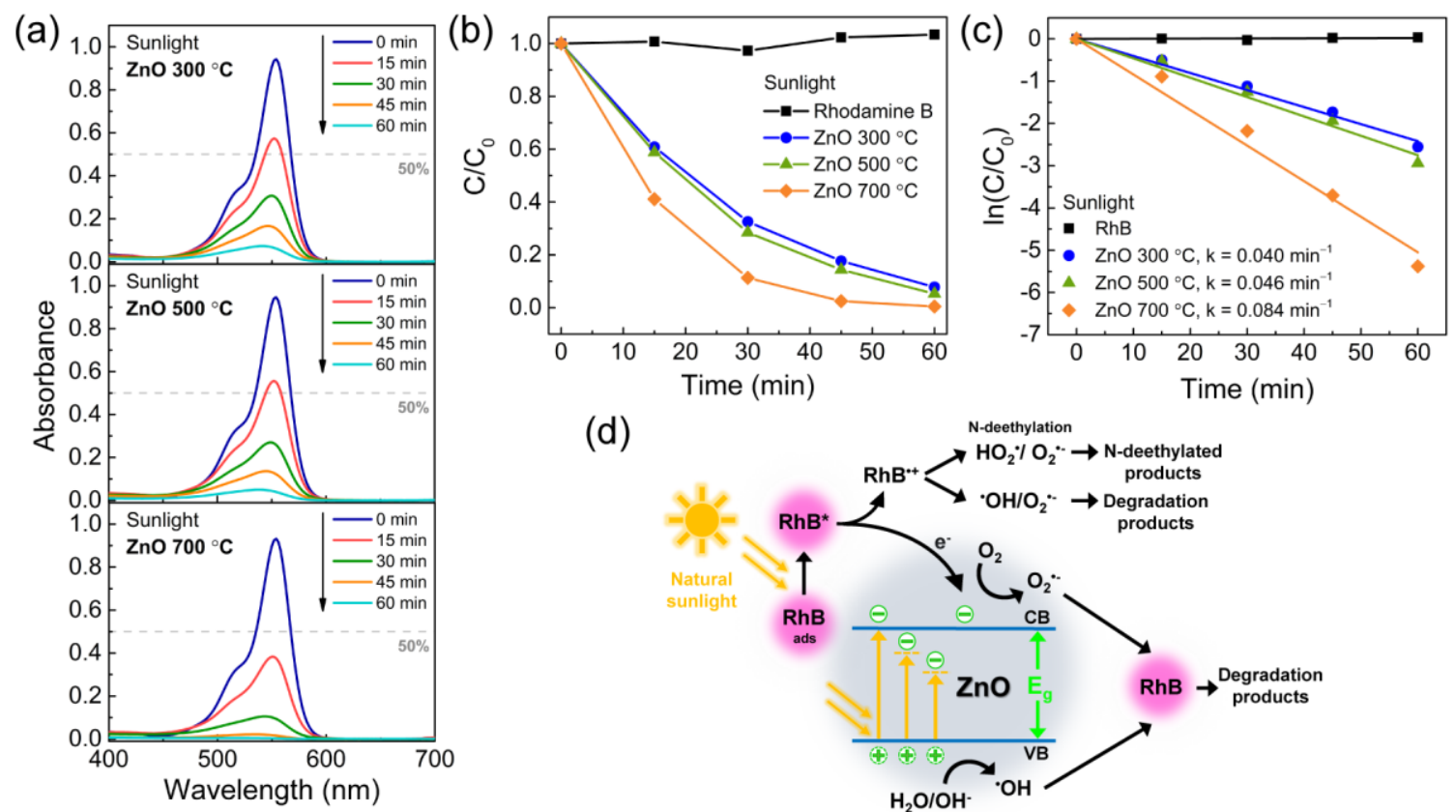

(d)

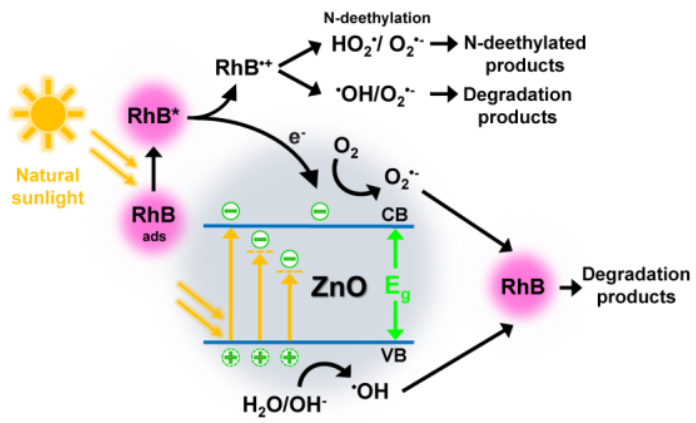

Figure 5. (a) Absorbance spectra of $\mathrm{RhB}$ recorded at different degradation times under solar light for ZnO samples calcinated at 300,500 , and $700{ }^{\circ} \mathrm{C}$. (b) Degradation ratio $C / C_{0}$ of $\mathrm{RhB}$ vs. sunlight exposure time for all the produced porous $\mathrm{ZnO}$ samples. (c) $\ln \left(C / C_{0}\right)$ vs. sunlight exposure time and the resultant degradation rates $k$ for each tested sample. (d) Solar light photocatalytic mechanism of $\mathrm{ZnO}$.

As mentioned before, the wide bandgap energy of $\mathrm{ZnO}$ limits its absorption in the visible range. Nevertheless, the porous $\mathrm{ZnO}$ nanostructures produced at 300,500 , and $700{ }^{\circ} \mathrm{C}$ have a calculated bandgap energy of $3.25,3.26$, and $3.26 \mathrm{eV}$, respectively, and an absorption edge starting at wavelengths longer than $400 \mathrm{~nm}$ (see Figure 3a). This means that the $\mathrm{ZnO}$ nanostructures have the ability to absorb a part of the incident solar light and create $\mathrm{e}^{-} / \mathrm{h}^{+}$ pairs that will originate radicals for the degradation of $\mathrm{RhB}$, as also demonstrated by the PL spectra obtained with different excitation wavelengths (Figure S3b). In addition, during sunlight photocatalysis, direct band-to-band excitation is much lower when compared to UV photocatalysis since solar light only comprises about $5 \%$ of UV radiation [129]. This fact suggests that under sunlight irradiation, most excitation transitions occur from the VB to energy levels within the bandgap of $\mathrm{ZnO}$. Wang et al. [117] used different types of active species scavengers to study the visible photocatalytic mechanism of $\mathrm{ZnO}$ nanorods and found that $\mathrm{h}^{+}$and ${ }^{\bullet} \mathrm{OH}$ were the main species involved in the photocatalytic degradation of RhB mediated by visible light. This finding suggests that energy levels deep inside the bandgap caused by bulk and surface defects may promote charge separation as they readily accept and trap the excited electrons, leaving behind the generated holes that will participate in the sunlight mediated degradation of $\mathrm{RhB}$.

As shown by Raman and FTIR analysis, the porous $\mathrm{ZnO}$ structures calcinated at 300 and $500{ }^{\circ} \mathrm{C}$ have a higher quantity of defects, impurities and surface-bonded $-\mathrm{OH}$ that resulted from an incomplete pyrolysis of the LZHC precursor. This is also corroborated 
by the lower crystallinity of these nanostructures when compared to the nanostructures obtained at $700{ }^{\circ} \mathrm{C}$ (Figure 1a), which indicates a higher relative concentration ratio of bulk to surface defects. In addition, from the diffuse reflectance spectra (Figure 3a), it is clear that calcination temperatures of 300 and $500^{\circ} \mathrm{C}$ yield $\mathrm{ZnO}$ with a higher absorption into the visible range than a temperature of $700{ }^{\circ} \mathrm{C}$. Hence, the $\mathrm{ZnO}$ nanostructures calcinated at lower temperatures showed a slight improvement under sunlight irradiation when compared to UV photocatalysis due to the defect levels within the bandgap of $\mathrm{ZnO}$, which promote charge generation and separation under sunlight and, subsequently, enhanced degradation of RhB.

\section{Conclusions}

In summary, porous $\mathrm{ZnO}$ nanostructures were successfully synthesized via a facile and fast hydrothermal method assisted by microwave irradiation followed by a calcination process at 300,500 , and $700{ }^{\circ} \mathrm{C}$. The effect of calcination temperature on the morphological, structural, and optical properties of the porous $\mathrm{ZnO}$ nanostructures was investigated. The produced samples were tested as photocatalysts in the degradation of RhB under UV and natural sunlight. All porous $\mathrm{ZnO}$ samples showed great photocatalytic activities under UV light, with RhB being degraded within $60 \mathrm{~min}$. Here, the porous $\mathrm{ZnO}$ obtained at $700{ }^{\circ} \mathrm{C}$ showed the best photocatalytic performance (degradation $>99 \%$ ) under UV light due to its high crystallinity and consequent low concentration ratio of bulk to surface defects. Moreover, it was demonstrated that these nanostructures can be reused several times without significant changes in the photocatalytic performance. When tested under sunlight, it was verified that porous $\mathrm{ZnO}$ nanostructures had a similar photocatalytic performance as when tested under UV light. Here, a RhB degradation superior to $99 \%$ was also obtained when using the $\mathrm{ZnO}$ nanostructures calcinated at $700{ }^{\circ} \mathrm{C}$ after only $60 \mathrm{~min}$ of sunlight exposure, due to the ability of $\mathrm{ZnO}$ to absorb light in the visible range and generate $\mathrm{e}^{-} / \mathrm{h}^{+}$ pairs as a result of defect levels within the bandgap of this metal oxide.

Supplementary Materials: The following are available online at https:/ /www.mdpi.com/article/10 .3390/ma14092385/s1, Figure S1: Nitrogen adsorption/desorption isotherms for the porous ZnO nanostructures, Figure S2: Raman spectrum of the LZHC precursor of ZnO, Figure S3: Deconvolution of the PL spectrum of the porous $\mathrm{ZnO}$ nanostructures calcinated at $700{ }^{\circ} \mathrm{C}$ and PL spectra under different excitation wavelengths.

Author Contributions: Conceptualization, S.H.F.; methodology, S.H.F.; investigation, S.H.F., M.M., M.J.O., A.R., D.N. and A.P.; writing—original draft preparation, S.H.F.; writing-review and editing, M.M, D.N., M.J.O., A.P., A.R., H.Á., E.F., and R.M.; supervision, H.Á., E.F., and R.M; funding acquisition, E.F. and R.M. All authors have read and agreed to the published version of the manuscript.

Funding: This work is funded by National Funds through FCT-Portuguese Foundation for Science and Technology, reference UIDB/50025/2020-2023 and FCT/MCTES. This work also received funding from the European Community's H2020 program under grant agreement No. 787410 (ERC-2018-AdG DIGISMART), No. 716510 (ERC-2016-StG TREND) and No. 952169 (SYNERGY, H2020-WIDESPREAD-2020-5, CSA). S. H. F. acknowledges FCT for the AdvaMTech PhD program scholarship PD/BD/114086/2015 and IDS-FunMat-INNO-2 project FPA2016/EIT/EIT RawMaterials Grant Agreement 17184. M.J.O. acknowledges FCT for the scholarship SFRH/BD/132057/2017 and MIT Portugal PhD Program.

Institutional Review Board Statement: Not applicable.

Informed Consent Statement: Not applicable.

Data Availability Statement: The data presented in this study are available on request from the corresponding author.

Conflicts of Interest: The authors declare no conflict of interest. 


\section{References}

1. Nidheesh, P.V.; Zhou, M.; Oturan, M.A. An overview on the removal of synthetic dyes from water by electrochemical advanced oxidation processes. Chemosphere 2018, 197, 210-227. [CrossRef]

2. Moreira, F.C.; Boaventura, R.A.R.; Brillas, E.; Vilar, V.J.P. Electrochemical advanced oxidation processes: A review on their application to synthetic and real wastewaters. Appl. Catal. B Environ. 2017, 202, 217-261. [CrossRef]

3. Brillas, E.; Martínez-Huitle, C.A. Decontamination of wastewaters containing synthetic organic dyes by electrochemical methods. An updated review. Appl. Catal. B Environ. 2015, 166-167, 603-643. [CrossRef]

4. Wang, Z.L. Zinc oxide nanostructures: Growth, properties and applications. J. Phys. Condens. Matter 2004, 16, R829-R858. [CrossRef]

5. Trandafilović, L.V.; Jovanović, D.J.; Zhang, X.; Ptasińska, S.; Dramićanin, M.D. Enhanced photocatalytic degradation of methylene blue and methyl orange by ZnO:Eu nanoparticles. Appl. Catal. B Environ. 2017, 203, 740-752. [CrossRef]

6. Ishioka, J.; Kogure, K.; Ofuji, K.; Kawaguchi, K.; Jeem, M.; Kato, T.; Shibayama, T.; Watanabe, S. In situ direct observation of photocorrosion in $\mathrm{ZnO}$ crystals in ionic liquid using a laser-equipped high-voltage electron microscope. AIP Adv. 2017, 7, 035220. [CrossRef]

7. Samadi, M.; Zirak, M.; Naseri, A.; Khorashadizade, E.; Moshfegh, A.Z. Recent progress on doped ZnO nanostructures for visible-light photocatalysis. Thin Solid Films 2016, 605, 2-19. [CrossRef]

8. Ali, A.M.; Emanuelsson, E.A.C.; Patterson, D.A. Photocatalysis with nanostructured zinc oxide thin films: The relationship between morphology and photocatalytic activity under oxygen limited and oxygen rich conditions and evidence for a Mars Van Krevelen mechanism. Appl. Catal. B Environ. 2010, 97, 168-181. [CrossRef]

9. Rezapour, M.; Talebian, N. Comparison of structural, optical properties and photocatalytic activity of ZnO with different morphologies: Effect of synthesis methods and reaction media. Mater. Chem. Phys. 2011, 129, 249-255. [CrossRef]

10. Baruah, S.; Sinha, S.S.; Ghosh, B.; Pal, S.K.; Raychaudhuri, A.K.; Dutta, J. Photoreactivity of ZnO nanoparticles in visible light: Effect of surface states on electron transfer reaction. J. Appl. Phys. 2009, 105, 074308. [CrossRef]

11. Pei, Z.; Ding, L.; Hu, J.; Weng, S.; Zheng, Z.; Huang, M.; Liu, P. Defect and its dominance in ZnO films: A new insight into the role of defect over photocatalytic activity. Appl. Catal. B Environ. 2013, 142-143, 736-743. [CrossRef]

12. Pant, H.R.; Park, C.H.; Pant, B.; Tijing, L.D.; Kim, H.Y.; Kim, C.S. Synthesis, characterization, and photocatalytic properties of ZnO nano-flower containing TiO2 NPs. Ceram. Int. 2012, 38, 2943-2950. [CrossRef]

13. Uddin, M.T.; Nicolas, Y.; Olivier, C.; Toupance, T.; Servant, L.; Müller, M.M.; Kleebe, H.J.; Ziegler, J.; Jaegermann, W. Nanostructured $\mathrm{SnO} 2-\mathrm{ZnO}$ heterojunction photocatalysts showing enhanced photocatalytic activity for the degradation of organic dyes. Inorg. Chem. 2012, 51, 7764-7773. [CrossRef] [PubMed]

14. Bai, X.; Wang, L.; Zong, R.; Lv, Y.; Sun, Y.; Zhu, Y. Performance enhancement of ZnO photocatalyst via synergic effect of surface oxygen defect and graphene hybridization. Langmuir 2013, 29, 3097-3105. [CrossRef] [PubMed]

15. Ahmad, M.; Ahmed, E.; Hong, Z.L.; Xu, J.F.; Khalid, N.R.; Elhissi, A.; Ahmed, W. A facile one-step approach to synthesizing $\mathrm{ZnO}$ /graphene composites for enhanced degradation of methylene blue under visible light. Appl. Surf. Sci. 2013, 274, $273-281$. [CrossRef]

16. Lee, H.J.; Kim, J.H.; Park, S.S.; Hong, S.S.; Lee, G.D. Degradation kinetics for photocatalytic reaction of methyl orange over Al-doped ZnO nanoparticles. J. Ind. Eng. Chem. 2015, 25, 199-206. [CrossRef]

17. Mahdavi, R.; Talesh, S.S.A. Sol-gel synthesis, structural and enhanced photocatalytic performance of Al doped $\mathrm{ZnO}$ nanoparticles. Adv. Powder Technol. 2017, 28, 1418-1425. [CrossRef]

18. Lee, K.M.; Lai, C.W.; Ngai, K.S.; Juan, J.C. Recent developments of zinc oxide based photocatalyst in water treatment technology: A review. Water Res. 2016, 88, 428-448. [CrossRef]

19. Wang, J.; Xia, Y.; Dong, Y.; Chen, R.; Xiang, L.; Komarneni, S. Defect-rich ZnO nanosheets of high surface area as an efficient visible-light photocatalyst. Appl. Catal. B Environ. 2016, 192, 8-16. [CrossRef]

20. Liu, S.; Li, C.; Yu, J.; Xiang, Q. Improved visible-light photocatalytic activity of porous carbon self-doped ZnO nanosheetassembled flowers. CrystEngComm 2011, 13, 2533-2541. [CrossRef]

21. Liu, J.; Hu, Z.Y.; Peng, Y.; Huang, H.W.; Li, Y.; Wu, M.; Ke, X.X.; Van Tendeloo, G.; Su, B.L. 2D ZnO mesoporous single-crystal nanosheets with exposed $\{0001\}$ polar facets for the depollution of cationic dye molecules by highly selective adsorption and photocatalytic decomposition. Appl. Catal. B Environ. 2016, 181, 138-145. [CrossRef]

22. Wang, L.; Li, X.; Zheng, Y.; Li, X.; Dong, W.; Tang, W.; Chen, B.; Li, C.; Zhang, T.; Xu, W. Nanostructured porous ZnO film with enhanced photocatalytic activity. Thin Solid Films 2011, 519, 5673-5678. [CrossRef]

23. Haibo, O.; Feng, H.J.; Cuiyan, L.; Liyun, C.; Jie, F. Synthesis of carbon doped ZnO with a porous structure and its solar-light photocatalytic properties. Mater. Lett. 2013, 111, 217-220. [CrossRef]

24. Nagaraja, R.; Kottam, N.; Girija, C.R.; Nagabhushana, B.M. Photocatalytic degradation of Rhodamine B dye under UV/solar light using ZnO nanopowder synthesized by solution combustion route. Powder Technol. 2012, 215-216, 91-97. [CrossRef]

25. Ait hssi, A.; Amaterz, E.; Labchir, N.; Atourki, L.; Bouderbala, I.Y.; Elfanaoui, A.; Benlhachemi, A.; Ihlal, A.; Bouabid, K. Electrodeposited ZnO Nanorods as Efficient Photoanodes for the Degradation of Rhodamine B. Phys. Status Solidi 2020, 217, 2000349. [CrossRef]

26. Manthina, V.; Agrios, A.G. Single-pot ZnO nanostructure synthesis by chemical bath deposition and their applications. NanoStruct. Nano-Objects 2016, 7, 1-11. 
27. Lupan, O.; Emelchenko, G.A.; Ursaki, V.V.; Chai, G.; Redkin, A.N.; Gruzintsev, A.N.; Tiginyanu, I.M.; Chow, L.; Ono, L.K.; Roldan Cuenya, B.; et al. Synthesis and characterization of $\mathrm{ZnO}$ nanowires for nanosensor applications. Mater. Res. Bull. 2010, 45, 1026-1032. [CrossRef]

28. Pimentel, A.; Rodrigues, J.; Duarte, P.; Nunes, D.; Costa, F.M.; Monteiro, T.; Martins, R.; Fortunato, E. Effect of solvents on ZnO nanostructures synthesized by solvothermal method assisted by microwave radiation: A photocatalytic study. J. Mater. Sci. 2015, 50, 5777-5787. [CrossRef]

29. Mahpeykar, S.M.; Koohsorkhi, J.; Ghafoori-fard, H. Ultra-fast microwave-assisted hydrothermal synthesis of long vertically aligned ZnO nanowires for dye-sensitized solar cell application. Nanotechnology 2012, 23, 165602. [CrossRef]

30. Qiu, Y.; Chen, W.; Yang, S. Facile hydrothermal preparation of hierarchically assembled, porous single-crystalline ZnO nanoplates and their application in dye-sensitized solar cells. J. Mater. Chem. 2010, 20, 1001-1006. [CrossRef]

31. Pimentel, A.; Nunes, D.; Duarte, P.; Rodrigues, J.; Costa, F.M.; Monteiro, T.; Martins, R.; Fortunato, E. Synthesis of long ZnO nanorods under microwave irradiation or conventional heating. J. Phys. Chem. C 2014, 118, 14629-14639. [CrossRef]

32. Pimentel, A.; Ferreira, S.H.; Nunes, D.; Calmeiro, T.; Martins, R.; Fortunato, E. Microwave Synthesized ZnO Nanorods Arrays for UV Sensors: A Seed Layer Annealing Temperature Study. Materials 2016, 9, 299. [CrossRef] [PubMed]

33. Ferreira, S.H.; Deuermeier, J.; Sequeira, S.; Nunes, D.; Gonçalves, A.M.F.; Martins, R.; Monteiro, R.C.C.; Fortunato, E. Industrial waste residue converted into value-added $\mathrm{ZnO}$ for optoelectronic applications. ACS Appl. Electron. Mater. 2020, 2, 1960-1969. [CrossRef]

34. Matias, M.L.; Nunes, D.; Pimentel, A.; Ferreira, S.H.; Borda d'Agua, R.; Duarte, M.P.; Fortunato, E.; Martins, R. Paper-Based Nanoplatforms for Multifunctional Applications. J. Nanomater. 2019, 2019, 6501923. [CrossRef]

35. Wojnarowicz, J.; Chudoba, T.; Lojkowski, W. A Review of Microwave Synthesis of Zinc Oxide Nanomaterials: Reactants, Process Parameters and Morphologies. Nanomaterials 2020, 10, 1086. [CrossRef] [PubMed]

36. Collins, M.J. Introduction to Microwave Chemistry. In Microwave Synthesis: Chemistry at the Speed of Light; Hayes, B.L., Ed.; CEM Publishing: Matthews, NC, USA, 2002; pp. 11-27. ISBN 0-9722229-01.

37. Mirzaei, A.; Neri, G. Microwave-assisted synthesis of metal oxide nanostructures for gas sensing application: A review. Sens. Actuators B Chem. 2016, 237, 749-775. [CrossRef]

38. Leonardi, S. Two-Dimensional Zinc Oxide Nanostructures for Gas Sensor Applications. Chemosensors 2017, 5, 17. [CrossRef]

39. Nunes, D.; Pimentel, A.; Goncalves, A.; Pereira, S.; Branquinho, R.; Barquinha, P.; Fortunato, E.; Martins, R. Metal oxide nanostructures for sensor applications. Semicond. Sci. Technol. 2019, 34. [CrossRef]

40. Moezzi, A.; McDonagh, A.M.; Cortie, M.B. Zinc oxide particles: Synthesis, properties and applications. Chem. Eng. J. 2012, 185-186, 1-22. [CrossRef]

41. Baruah, S.; Dutta, J. Hydrothermal growth of ZnO nanostructures. Sci. Technol. Adv. Mater. 2009, 10, 013001. [CrossRef]

42. Schmidt-Mende, L.; MacManus-Driscoll, J.L. ZnO - nanostructures, defects, and devices. Mater. Today 2007, 10, 40-48. [CrossRef]

43. Filip, A.; Musat, V.; Tigau, N.; Polosan, S.; Pimentel, A.; Ferreira, S.; Gomes, D.; Calmeiro, T.; Martins, R.; Fortunato, E. ZnO nanostructures grown on ITO coated glass substrate by hybrid microwave-assisted hydrothermal method. Optik (Stuttg). 2020, 208, 1-8. [CrossRef]

44. Jang, J.S.; Lee, S.E.; Choi, S.J.; Koo, W.T.; Kim, D.H.; Shin, H.; Park, H.J.; Kim, I.D. Heterogeneous, Porous 2D Oxide Sheets via Rapid Galvanic Replacement: Toward Superior HCHO Sensing Application. Adv. Funct. Mater. 2019, 29, 1-10. [CrossRef]

45. Huang, A.; He, Y.; Zhou, Y.; Zhou, Y.; Yang, Y.; Zhang, J.; Luo, L.; Mao, Q.; Hou, D.; Yang, J. A review of recent applications of porous metals and metal oxide in energy storage, sensing and catalysis. J. Mater. Sci. 2019, 54, 949-973. [CrossRef]

46. Sk, M.M.; Yue, C.Y.; Ghosh, K.; Jena, R.K. Review on advances in porous nanostructured nickel oxides and their composite electrodes for high-performance supercapacitors. J. Power Sources 2016, 308, 121-140. [CrossRef]

47. Butburee, T.; Bai, Y.; Wang, H.; Chen, H.; Wang, Z.; Liu, G.; Zou, J.; Khemthong, P.; Lu, G.Q.M.; Wang, L. 2D Porous TiO2 Single-Crystalline Nanostructure Demonstrating High Photo-Electrochemical Water Splitting Performance. Adv. Mater. 2018, 30, 1-8. [CrossRef]

48. Xie, X.; Wang, X.; Tian, J.; Song, X.; Wei, N.; Cui, H. Growth of porous ZnO single crystal hierarchical architectures with ultrahigh sensing performances to ethanol and acetone gases. Ceram. Int. 2017, 43, 1121-1128. [CrossRef]

49. Jin, Z.; Zhang, Y.X.; Meng, F.L.; Jia, Y.; Luo, T.; Yu, X.Y.; Wang, J.; Liu, J.H.; Huang, X.J. Facile synthesis of porous single crystalline $\mathrm{ZnO}$ nanoplates and their application in photocatalytic reduction of $\mathrm{Cr}(\mathrm{VI})$ in the presence of phenol. J. Hazard. Mater. 2014, 276, 400-407. [CrossRef]

50. Song, B.; Wang, Y.; Cui, X.; Kou, Z.; Si, L.; Tian, W.; Yi, C.; Wei, T.; Sun, Y. A Series of Unique Architecture Building of Layered Zinc Hydroxides: Self-Assembling Stepwise Growth of Layered Zinc Hydroxide Carbonate and Conversion into Three-Dimensional ZnO. Cryst. Growth Des. 2016, 16, 887-894. [CrossRef]

51. Bitenc, M.; Marinšek, M.; Crnjak Orel, Z. Preparation and characterization of zinc hydroxide carbonate and porous zinc oxide particles. J. Eur. Ceram. Soc. 2008, 28, 2915-2921. [CrossRef]

52. Gu, F.; You, D.; Wang, Z.; Han, D.; Guo, G. Improvement of gas-sensing property by defect engineering in microwave-assisted synthesized 3D ZnO nanostructures. Sens. Actuators B Chem. 2014, 204, 342-350. [CrossRef]

53. Zhang, Y.; Liu, C.; Gong, F.; Jiu, B.; Li, F. Large scale synthesis of hexagonal simonkolleit nanosheets for ZnO gas sensors with enhanced performances. Mater. Lett. 2017, 186, 7-11. [CrossRef] 
54. Teng, Y.; Mo, M.; Li, Y.; Xue, J.; Zhao, H. Amorphous carbon-coated ZnO porous nanosheets: Facile fabrication and application in lithium- and sodium-ion batteries. J. Alloys Compd. 2018, 744, 712-720. [CrossRef]

55. Li, B.; Wang, Y. Hierarchically assembled porous $\mathrm{ZnO}$ microstructures and applications in a gas sensor. Superlattices Microstruct. 2011, 49, 433-440. [CrossRef]

56. Ferreira, S.H.; Rovisco, A.; dos Santos, A.; Águas, H.; Igreja, R.; Barquinha, P.; Fortunato, E.; Martins, R. Porous ZnO nanostructures synthesized by microwave hydrothermal method for energy harvesting applications. In Nanopores; Ameen, S., Ed.; IntechOpen: London, UK, 2021; ISBN 978-1-83880-210-3.

57. Ji, X.; Wang, A.; Li, G.; Lu, Z. Controllable synthesis and photocatalytic properties of ZnO hierarchical flower-like porous nanostructures. Micro Nano Lett. 2016, 11, 753-757. [CrossRef]

58. Sotomayor, F.; Cychosz, K.A.; Thommes, M. Characterization of Micro / Mesoporous Materials by Physisorption: Concepts and Case Studies. Accounts Mater. Surf. Res. 2018, 3, 34-50.

59. Das, D.; Mondal, P. Photoluminescence phenomena prevailing in c-axis oriented intrinsic ZnO thin films prepared by RF magnetron sputtering. RSC Adv. 2014, 4, 35735-35743. [CrossRef]

60. Özgür, Ü.; Alivov, Y.I.; Liu, C.; Teke, A.; Reshchikov, M.A.; Doğan, S.; Avrutin, V.; Cho, S.J.; Morko, H. A comprehensive review of ZnO materials and devices. J. Appl. Phys. 2005, 98, 1-103. [CrossRef]

61. Cuscó, R.; Alarcón-Lladó, E.; Ibáñez, J.; Artús, L.; Jiménez, J.; Wang, B.; Callahan, M.J. Temperature dependence of Raman scattering in ZnO. Phys. Rev. B 2007, 75, 165202. [CrossRef]

62. Liu, D.; Lv, Y.; Zhang, M.; Liu, Y.; Zhu, Y.; Zong, R.; Zhu, Y. Defect-related photoluminescence and photocatalytic properties of porous ZnO nanosheets. J. Mater. Chem. A 2014, 2, 15377-15388. [CrossRef]

63. Gouadec, G.; Colomban, P. Raman Spectroscopy of nanomaterials: How spectra relate to disorder, particle size and mechanical properties. Prog. Cryst. Growth Charact. Mater. 2007, 53, 1-56. [CrossRef]

64. Tuschel, D. Why are the Raman spectra of crystalline and amorphous solids different? Spectroscopy 2017, 32, 26-33.

65. Song, Y.; Zhang, S.; Zhang, C.; Yang, Y.; Lv, K. Raman spectra and microstructure of zinc oxide irradiated with swift heavy ion. Crystals 2019, 9, 395. [CrossRef]

66. Russo, V.; Ghidelli, M.; Gondoni, P.; Casari, C.S.; Li Bassi, A. Multi-wavelength Raman scattering of nanostructured Al-doped zinc oxide. J. Appl. Phys. 2014, 115, 073508. [CrossRef]

67. Daumann, S.; Andrzejewski, D.; Di Marcantonio, M.; Hagemann, U.; Wepfer, S.; Vollkommer, F.; Bacher, G.; Epple, M.; Nannen, E. Water-free synthesis of $\mathrm{ZnO}$ quantum dots for application as an electron injection layer in light-emitting electrochemical cells. $J$. Mater. Chem. C 2017, 5, 2344-2351. [CrossRef]

68. Sharma, R.; Alam, F.; Sharma, A.K.; Dutta, V.; Dhawan, S.K. ZnO anchored graphene hydrophobic nanocomposite-based bulk heterojunction solar cells showing enhanced short-circuit current. J. Mater. Chem. C 2014, 2, 8142-8151. [CrossRef]

69. Alias, S.S.; Ismail, A.B.; Mohamad, A.A. Effect of $\mathrm{pH}$ on $\mathrm{ZnO}$ nanoparticle properties synthesized by sol-gel centrifugation. J. Alloys Compd. 2010, 499, 231-237. [CrossRef]

70. Bitenc, M.; Podbršček, P.; Dubek, P.; Bernstorff, S.; Draić, G.; Orel, B.; Orel, Z.C. The growth mechanism of zinc oxide and hydrozincite: A study using electron microscopies and in situ SAXS. CrystEngComm 2012, 14, 3080-3088. [CrossRef]

71. Bitenc, M.; Podbršček, P.; Dubček, P.; Bernstorff, S.; Dražić, G.; Orel, B.; Pejovnik, S.; Orel, Z.C. In and Ex situ studies of the formation of layered microspherical hydrozincite as precursor for ZnO. Chem. A Eur. J. 2010, 16, 11481-11488. [CrossRef]

72. Hales, M.C.; Frost, R.L. Synthesis and vibrational spectroscopic characterisation of synthetic hydrozincite and smithsonite. Polyhedron 2007, 26, 4955-4962. [CrossRef]

73. Dorranian, D.; Solati, E.; Dejam, L. Photoluminescence of ZnO nanoparticles generated by laser ablation in deionized water. Appl. Phys. A Mater. Sci. Process. 2012, 109, 307-314. [CrossRef]

74. Xingfu, Z.; Zhaolin, H.; Yiqun, F.; Su, C.; Weiping, D.; Nanping, X. Microspheric organization of multilayered ZnO nanosheets with hierarchically porous structures. J. Phys. Chem. C 2008, 112, 11722-11728. [CrossRef]

75. Wang, X.; Cai, W.; Lin, Y.; Wang, G.; Liang, C. Mass production of micro/nanostructured porous ZnO plates and their strong structurally enhanced and selective adsorption performance for environmental remediation. J. Mater. Chem. 2010, 20, 8582-8590 [CrossRef]

76. Mishra, V.; Warshi, M.K.; Sati, A.; Kumar, A.; Mishra, V.; Sagdeo, A.; Kumar, R.; Sagdeo, P.R. Diffuse reflectance spectroscopy: An effective tool to probe the defect states in wide band gap semiconducting materials. Mater. Sci. Semicond. Process. 2018, 86, 151-156. [CrossRef]

77. Huang, N.; Shu, J.; Wang, Z.; Chen, M.; Ren, C.; Zhang, W. One-step pyrolytic synthesis of ZnO nanorods with enhanced photocatalytic activity and high photostability under visible light and UV light irradiation. J. Alloys Compd. 2015, 648, 919-929. [CrossRef]

78. Akir, S.; Barras, A.; Coffinier, Y.; Bououdina, M.; Boukherroub, R.; Omrani, A.D. Eco-friendly synthesis of ZnO nanoparticles with different morphologies and their visible light photocatalytic performance for the degradation of Rhodamine B. Ceram. Int. 2016, 42, 10259-10265. [CrossRef]

79. Viezbicke, B.D.; Patel, S.; Davis, B.E.; Birnie, D.P. Evaluation of the Tauc method for optical absorption edge determination: ZnO thin films as a model system. Phys. Status Solidi Basic Res. 2015, 252, 1700-1710. [CrossRef]

80. Vempati, S.; Mitra, J.; Dawson, P. One-step synthesis of ZnO nanosheets: A blue-white fluorophore. Nanoscale Res. Lett. 2012, 7, 1-10. [CrossRef] 
81. Rodrigues, J.; Ben Sedrine, N.; Correia, M.R.; Monteiro, T. Photoluminescence investigations of ZnO micro/nanostructures. Mater. Today Chem. 2020, 16, 100243. [CrossRef]

82. Norek, M. Approaches to enhance UV light emission in ZnO nanomaterials. Curr. Appl. Phys. 2019, 19, 867-883. [CrossRef]

83. Janotti, A.; Van De Walle, C.G. Native point defects in ZnO. Phys. Rev. B 2007, 76, 165202. [CrossRef]

84. Zeng, H.; Duan, G.; Li, Y.; Yang, S.; Xu, X.; Cai, W. Blue luminescence of ZnO nanoparticles based on non-equilibrium processes: Defect origins and emission controls. Adv. Funct. Mater. 2010, 20, 561-572. [CrossRef]

85. Morkoç, H.; Özgür, Ü. Zinc Oxide Fundamentals, Materials and Device Technology; WILEY-VCH: Weinheim, Germany, 2009; ISBN 978-3-527-40813-9.

86. Djurišić, A.B.; Leung, Y.H.; Tam, K.H.; Hsu, Y.F.; Ding, L.; Ge, W.K.; Zhong, Y.C.; Wong, K.S.; Chan, W.K.; Tam, H.L.; et al. Defect emissions in $\mathrm{ZnO}$ nanostructures. Nanotechnology 2007, 18, 095702. [CrossRef]

87. Djurišić, A.B.; Leung, Y.H. Optical properties of ZnO nanostructures. Small 2006, 2, 944-961. [CrossRef]

88. Li, D.; Leung, Y.H.; Djurišić, A.B.; Liu, Z.T.; Xie, M.H.; Shi, S.L.; Xu, S.J.; Chan, W.K. Different origins of visible luminescence in ZnO nanostructures fabricated by the chemical and evaporation methods. Appl. Phys. Lett. 2004, 85, 1601-1603. [CrossRef]

89. Ahn, C.H.; Kim, Y.Y.; Kim, D.C.; Mohanta, S.K.; Cho, H.K. A comparative analysis of deep level emission in ZnO layers deposited by various methods. J. Appl. Phys. 2009, 105, 1-6. [CrossRef]

90. Janotti, A.; Van de Walle, C.G. Fundamentals of zinc oxide as a semiconductor. Reports Prog. Phys. 2009, 72, 126501. [CrossRef]

91. Kayaci, F.; Vempati, S.; Donmez, I.; Biyikli, N.; Uyar, T. Role of zinc interstitials and oxygen vacancies of ZnO in photocatalysis: A bottom-up approach to control defect density. Nanoscale 2014, 6, 10224-10234. [CrossRef]

92. Galdámez-Martinez, A.; Santana, G.; Güell, F.; Martínez-Alanis, P.R.; Dutt, A. Photoluminescence of zno nanowires: A review. Nanomaterials 2020, 10, 857. [CrossRef]

93. Cao, B.; Cai, W.; Zeng, H. Temperature-dependent shifts of three emission bands for ZnO nanoneedle arrays. Appl. Phys. Lett. 2006, 88, 18-21. [CrossRef]

94. Camarda, P.; Messina, F.; Vaccaro, L.; Agnello, S.; Buscarino, G.; Schneider, R.; Popescu, R.; Gerthsen, D.; Lorenzi, R.; Gelardi, F.M.; et al. Luminescence mechanisms of defective ZnO nanoparticles. Phys. Chem. Chem. Phys. 2016, 18, 16237-16244. [CrossRef] [PubMed]

95. Camarda, P.; Vaccaro, L.; Messina, F.; Cannas, M. Oxidation of Zn nanoparticles probed by online optical spectroscopy during nanosecond pulsed laser ablation of a Zn plate in H2O. Appl. Phys. Lett. 2015, 107, 013103. [CrossRef]

96. Ye, J.D.; Gu, S.L.; Qin, F.; Zhu, S.M.; Liu, S.M.; Zhou, X.; Liu, W.; Hu, L.Q.; Zhang, R.; Shi, Y.; et al. Correlation between green luminescence and morphology evolution of ZnO films. Appl. Phys. A Mater. Sci. Process. 2005, 81, 759-762. [CrossRef]

97. Ton-That, C.; Weston, L.; Phillips, M.R. Characteristics of point defects in the green luminescence from Zn- and O-rich ZnO. Phys. Rev. B - Condens. Matter Mater. Phys. 2012, 86, 1-5. [CrossRef]

98. Leung, Y.H.; Chen, X.Y.; Ng, A.M.C.; Guo, M.Y.; Liu, F.Z.; Djurišić, A.B.; Chan, W.K.; Shi, X.Q.; Van Hove, M.A. Green emission in ZnO nanostructures - Examination of the roles of oxygen and zinc vacancies. Appl. Surf. Sci. 2013, 271, 202-209. [CrossRef]

99. Fabbri, F.; Villani, M.; Catellani, A.; Calzolari, A.; Cicero, G.; Calestani, D.; Calestani, G.; Zappettini, A.; Dierre, B.; Sekiguchi, T.; et al. Zn vacancy induced green luminescence on non-polar surfaces in ZnO nanostructures. Sci. Rep. 2014, 4, 1-6. [CrossRef]

100. Heo, Y.W.; Norton, D.P.; Pearton, S.J. Origin of green luminescence in ZnO thin film grown by molecular-beam epitaxy. J. Appl. Phys. 2005, 98, 073502. [CrossRef]

101. Bera, A.; Basak, D. Correlation between the microstructure and the origin of the green luminescence in $\mathrm{ZnO}$ : A case study on the thin films and nanowires. Chem. Phys. Lett. 2009, 476, 262-266. [CrossRef]

102. Tam, K.H.; Cheung, C.K.; Leung, Y.H.; Djuris, A.B.; Fung, S.; Kwok, W.M.; Chan, W.K.; Phillips, D.L.; Ding, L.; Ge, W.K. Defects in ZnO Nanorods Prepared by a Hydrothermal Method. J. Phys. Chem. B 2006, 110, 20865-20871. [CrossRef]

103. Panigrahy, B.B.; Aslam, M.; Misra, D.S.; Ghosh, M.; Bahadur, D. Defect-Related Emissions and Magnetization Properties of ZnO Nanorods. Adv. Funct. Mater. 2010, 20, 1161-1165. [CrossRef]

104. Manzano, C.V.; Alegre, D.; Caballero-Calero, O.; Alén, B.; Martín-González, M.S. Synthesis and luminescence properties of electrodeposited ZnO films. J. Appl. Phys. 2011, 110, 043538. [CrossRef]

105. Rahman, Q.I.; Ahmad, M.; Misra, S.K.; Lohani, M. Effective photocatalytic degradation of rhodamine B dye by ZnO nanoparticles. Mater. Lett. 2013, 91, 170-174. [CrossRef]

106. Byrappa, K.; Subramani, A.; Ananda, S.; Rai, K. Photocatalytic degradation of rhodamine B dye using hydrothermally synthesized ZnO. Bull. Mater. 2006, 29, 433-438. [CrossRef]

107. Nunes, D.; Pimentel, A.; Santos, L.; Barquinha, P.; Fortunato, E.; Martins, R. Photocatalytic TiO2 Nanorod Spheres and Arrays Compatible with Flexible Applications. Catalysts 2017, 7, 60. [CrossRef]

108. Nunes, D.; Pimentel, A.; Pinto, J.V.; Calmeiro, T.R.; Nandy, S.; Barquinha, P.; Pereira, L.; Carvalho, P.A.; Fortunato, E.; Martins, R. Photocatalytic behavior of TiO2 films synthesized by microwave irradiation. Catal. Today 2016, 278, 262-270. [CrossRef]

109. Le, H.A.; Linh, L.T.; Chin, S.; Jurng, J. Photocatalytic degradation of methylene blue by a combination of TiO2-anatase and coconut shell activated carbon. Powder Technol. 2012, 225, 167-175. [CrossRef]

110. Konstantinou, I.K.; Albanis, T.A. TiO2-assisted photocatalytic degradation of azo dyes in aqueous solution: Kinetic and mechanistic investigations: A review. Appl. Catal. B Environ. 2004, 49, 1-14. [CrossRef]

111. Bizarro, M. High photocatalytic activity of $\mathrm{ZnO}$ and $\mathrm{ZnO}$ :Al nanostructured films deposited by spray pyrolysis. Appl. Catal. $B$ Environ. 2010, 97, 198-203. [CrossRef] 
112. Wang, S.; Kuang, P.; Cheng, B.; Yu, J.; Jiang, C. ZnO hierarchical microsphere for enhanced photocatalytic activity. J. Alloys Compd. 2018, 741, 622-632. [CrossRef]

113. Bizarro, M.; Sánchez-Arzate, A.; Garduño-Wilches, I.; Alonso, J.C.; Ortiz, A. Synthesis and characterization of ZnO and ZnO:Al by spray pyrolysis with high photocatalytic properties. Catal. Today 2011, 166, 129-134. [CrossRef]

114. Pimentel, A.; Nunes, D.; Pereira, S.; Martins, R.; Fortunato, E. Photocatalytic Activity of TiO2 Nanostructured Arrays Prepared by Microwave-Assisted Solvothermal Method. In Semiconductor Photocatalysis - Materials, Mechanisms and Applications; Cao, W., Ed.; Intech: London, UK, 2016; pp. 81-103.

115. Kusiak-Nejman, E.; Wojnarowicz, J.; Morawski, A.W.; Narkiewicz, U.; Sobczak, K.; Gierlotka, S.; Lojkowski, W. Size-dependent effects of $\mathrm{ZnO}$ nanoparticles on the photocatalytic degradation of phenol in a water solution. Appl. Surf. Sci. 2021, $541,148416$. [CrossRef]

116. Zhou, W.; Fu, H. Defect-mediated electron-hole separation in semiconductor photocatalysis. Inorg. Chem. Front. 2018, 5, 1240-1254. [CrossRef]

117. Wang, J.; Chen, R.; Xia, Y.; Wang, G.; Zhao, H.; Xiang, L.; Komarneni, S. Cost-effective large-scale synthesis of oxygen-defective $\mathrm{ZnO}$ photocatalyst with superior activities under UV and visible light. Ceram. Int. 2017, 43, 1870-1879. [CrossRef]

118. Wang, J.; Wang, Z.; Huang, B.; Ma, Y.; Liu, Y.; Qin, X.; Zhang, X.; Dai, Y. Oxygen vacancy induced band-gap narrowing and enhanced visible light photocatalytic activity of ZnO. ACS Appl. Mater. Interfaces 2012, 4, 4024-4030. [CrossRef] [PubMed]

119. Kong, M.; Li, Y.; Chen, X.; Tian, T.; Fang, P.; Zheng, F.; Zhao, X. Tuning the relative concentration ratio of bulk defects to surface defects in TiO2 nanocrystals leads to high photocatalytic efficiency. J. Am. Chem. Soc. 2011, 133, 16414-16417. [CrossRef] [PubMed]

120. Hong, Y.; Tian, C.; Jiang, B.; Wu, A.; Zhang, Q.; Tian, G.; Fu, H. Facile synthesis of sheet-like ZnO assembly composed of small $\mathrm{ZnO}$ particles for highly efficient photocatalysis. J. Mater. Chem. A 2013, 1, 5700-5708. [CrossRef]

121. Zhuang, J.; Dai, W.; Tian, Q.; Li, Z.; Xie, L.; Wang, J.; Liu, P.; Shi, X.; Wang, D. Photocatalytic degradation of RhB over TiO2 bilayer films: Effect of defects and their location. Langmuir 2010, 26, 9686-9694. [CrossRef] [PubMed]

122. Li, X.; Ye, J. Photocatalytic degradation of rhodamine B over $\mathrm{Pb} 3 \mathrm{Nb} 4 \mathrm{O} 13$ / fumed $\mathrm{SiO} 2$ composite under visible light irradiation. J. Phys. Chem. C 2007, 111, 13109-13116. [CrossRef]

123. Saison, T.; Gras, P.; Chemin, N.; Chanéac, C.; Durupthy, O.; Brezová, V.; Colbeau-Justin, C.; Jolivet, J.P. New insights into Bi2WO6 properties as a visible-light photocatalyst. J. Phys. Chem. C 2013, 117, 22656-22666. [CrossRef]

124. Alam, U.; Khan, A.; Raza, W.; Khan, A.; Bahnemann, D. Highly efficient Y and V co-doped ZnO photocatalyst with enhanced dye sensitized visible light photocatalytic activity. Catal. Today 2017, 284, 169-178. [CrossRef]

125. Abou-Gamra, Z.M.; Ahmed, M.A.; Hamza, M.A. Investigation of commercial $\mathrm{PbCrO} 4 / \mathrm{TiO} 2$ for photodegradation of rhodamine $\mathrm{B}$ in aqueous solution by visible light. Nanotechnol. Environ. Eng. 2017, 2, 12. [CrossRef]

126. Neena, D.; Kondamareddy, K.K.; Bin, H.; Lu, D.; Kumar, P.; Dwivedi, R.K.; Pelenovich, V.O.; Zhao, X.Z.; Gao, W.; Fu, D. Enhanced visible light photodegradation activity of $\mathrm{RhB} / \mathrm{MB}$ from aqueous solution using nanosized novel Fe-Cd co-modified ZnO. Sci. Rep. 2018, 8, 1-12.

127. Bozetine, H.; Wang, Q.; Barras, A.; Li, M.; Hadjersi, T.; Szunerits, S.; Boukherroub, R. Green chemistry approach for the synthesis of $\mathrm{ZnO}$-carbon dots nanocomposites with good photocatalytic properties under visible light. J. Colloid Interface Sci. 2016, 465, 286-294. [CrossRef] [PubMed]

128. Rovisco, A.; Branquinho, R.; Deuermeier, J.; Freire, T.; Fortunato, E.; Martins, R.; Barquinha, P. Shape Effect of Zinc-Tin Oxide Nanostructures on Photodegradation of Methylene Blue and Rhodamine B under UV and Visible Light. ACS Appl. Nano Mater. 2021, 4, 1149-1161. [CrossRef]

129. Solar and Ultraviolet Radiation. Available online: https://www.ncbi.nlm.nih.gov/books/NBK304366/ (accessed on 29 July 2020). 